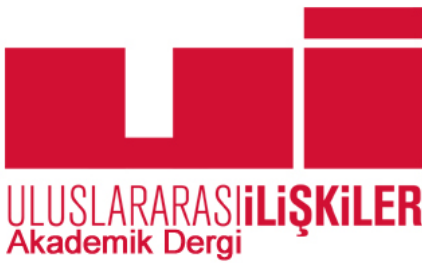

Yayın ilkeleri, izinler ve abonelik hakkında ayrıntılı bilgi:

E-mail: bilgi@uidergisi.com.tr

Web: www.uidergisi.com.tr

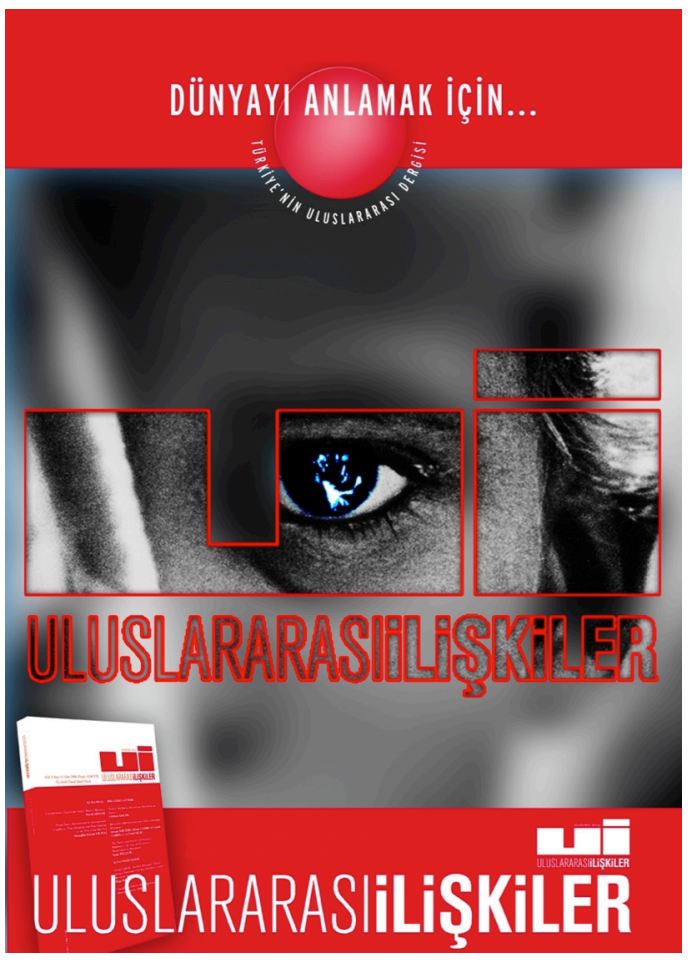

\author{
Eleştirel Bir Literatür Değerlendirmesi: \\ Dışlamadan Sınırlı Tanımaya, \\ Uluslararası İlişkiler Kuramları ve Marksizm \\ Ilhan UZGEL* ve Nazan BEDİRHANOĞLU** \\ * Prof. Dr., Ankara Üniversitesi, Uluslararası İlişkiler Bölümü \\ ** Arş. Gör., Ankara Üniversitesi, Uluslararası İlişkiler Bölümü
}

Bu makaleye atıf için: Uzgel, İlhan; Bedirhanoğlu, Nazan, "Eleștirel Bir Literatür Değerlendirmesi: Dışlamadan Sınırlı Tanımaya, Uluslararası İlişkiler Kuramları ve Marksizm", Uluslararası Ilişskiler, Cilt 12, Sayı 46, s. 105-130.

Bu makalenin tüm hakları Uluslararası İlişkiler Konseyi Derneği’ne aittir. Önceden yazılı izin alınmadan hiç bir iletişim, kopyalama ya da yayın sistemi kullanılarak yeniden yayımlanamaz, çoğaltılamaz, dağıtılamaz, satılamaz veya herhangi bir şekilde kamunun ücretli/ücretsiz kullanımına sunulamaz. Akademik ve haber amaçlı kısa alıntılar bu kuralın dışındadır.

Aksi belirtilmediği sürece Uluslararası İlişkiler'de yayınlanan yazılarda belirtilen fikirler yalnızca yazarına/yazarlarına aittir. UIKK Derneğini, editörleri ve diğer yazarları bağlamaz.

Uluslararası İlişkiler Konseyi Derneği | Uluslararası İliş kiler Dergisi

Web: www.uidergisi.com.tr | E- Posta: bilgi@uidergisi.com.tr 


\title{
Eleştirel Bir Literatür Değerlendirmesi: Dişlamadan Sınırlı Tanımaya, Uluslararası İlişkiler Kuramları ve Marksizm
}

\author{
Illhan UZGEL \\ Prof. Dr., Uluslararası İlişkiler Bölümü, Ankara Üniversitesi, Ankara. E-posta: uzgel@politics.ankara.edu.tr.
}

\section{Nazan BEDİRHANOĞLU}

Arş. Gör., Uluslararası İlişkiler Bölümü, Ankara Üniversitesi, Ankara. E-posta: Nazan.Bedirhanoglu@politics.ankara.edu.tr.

\begin{abstract}
ÖZET
Bu çalışma, Uluslararası İlişkiler kuramları ve Marksizm ilişkisini inceleyen eleştirel bir literatür değerlendirmesidir. Tarihsel olarak Uluslararası İlişkiler disiplini Marksizm’i epistemolojik ve metodolojik olarak dışarıda tutacak şekilde kurulmuş, 1980'lerden sonra ise Marksizm ancak sınırlı șekilde ve dönüştürülerek disipline dâhil edilmiştir. $\mathrm{Bu}$ dışlama hali daha çok ABD merkezli ise de, özellikle 1990'lardan itibaren ABD dışındaki Uluslararası İlişkiler çalışanlarının Marksizm ile girdikleri diyalog da disiplin içinde istisna olarak kalmıştır. Öte yandan, Marksizm ise Uluslararası İlişkilerin hegemonik dünyasından uzak durup, konuyu daha çok Emperyalizm kuramları çerçevesinde değerlendirirken, son yıllarda Marksist Uluslararası İlişkiler literatüründe küreselleşme bağlamında bir canlanma dikkati çekmektedir. Marksizm gibi uluslararası ilişkilere alternatif bakış geliştiren diğer sistem karşıtı tarihsel maddeci yaklaşımlar da disiplin tarafından görmezden gelinmiştir.
\end{abstract}

Anahtar Kelimeler: Marksizm, Uluslararası İlişkiler Kuramları, Emperyalizm .

\section{A Critical Literature Review: Theories of International Relations and Marxism, from Exclusion to Limited Recognition}

\begin{abstract}
This study is a critical literature review on the relationship between Marxism and the theories of International Relations. The discipline of International Relations historically excluded Marxism both methodologically and epistemologically. With the 1980s Marxism was slowly included in the discipline by way of depriving it of its essential content. While this exclusion was more US-centered, intellectual exchanges of the International Relations scholars outside the United States with Marxism since the 1990s also remained as an exception. While Marxism basically analyzed international relations through the theories of Imperialism, more recently there was a revival in the Marxist debate of international relations in the context of globalization. Similar to Marxism, the contributions by anti-systemic historical materialists leading to alternative perspectives on international relations have also been systematically ignored by the International Relations discipline.
\end{abstract}

Keywords: Marxism, Theories of International Relations, Imperialism. 


\section{Giriş}

Marksizm, siyasal teoriden resmi ideolojiye kadar uzanan geniş bir yelpazede, düşünce tarihini ve bütün sosyal bilim dallarını etkilerken, en az etki yarattığı disiplinlerden biri Uluslararası İlişkiler olmuştur. ${ }^{1}$ Bu kayıtsızlık hali o kadar belirgindir ki, SSCB ve Çin Halk Cumhuriyeti gibi ülkelerin ideolojilerine temel olan Marksizm bu ülkelerin uluslararası politikada yarattığı etkinin bir benzerini Uluslararası İlişkiler disiplininde yaratamamıştır.

Marksizm ve Uluslararası İlişkilerin birbirleriyle ilişkilendirilmemiş ya da sınırlı bir ilişkiye girmiş olmalarının öncelikle yapısal nedenleri vardır. Marksizm dünyaya baktığında ulusları değil toplumsal sınıfları görür. Devletin eylemlerinin sınıfsal anlamıyla ilgilenir; dış politikayı kendi içinde bir siyasal süreç olarak değil, belli sınıfsal çıkarların siyasal ifadesi olarak tanımlar. Uluslararası İlişkiler ise, kuruluşu itibariyle, kapitalizmi üretim biçimi, liberalizmi siyasal ideoloji olarak benimseyen, Batı merkezli, Anglosakson ve son aşamada ABD temelli bir disiplindir. Dolayısıyla, Uluslararası İlişkilerin, "tarihin taşıyıcı öznesi” olarak tanımlanan işçi sınıfı tarafından devrimle kapitalist üretim ilişkilerini yıkmayı hedefleyen Marksizm’i diğer Uluslararası İlişkiler kuramlarıyla aynı zeminde ele almasını beklemek gerçekçi değildir.

İlk Uluslararası İlişkiler kürsülerinin açıldığı 1920’lerden 1970’lerin sonuna dek disiplin, gerek düşünce tarihinde, gerekse dünya siyasetinde etki yaratmış bu düşünce geleneğini görmezden gelmiş; bütün yaklaşım, yöntem ve epistemolojisini Marksizm’i dışarıda bırakacak şekilde kurgulamıştır. Bu ihmal, dışlama ve uzak durma hali nedeniyle ana akım Uluslararası İlişkiler bu tavrın kendisinden bile bahsetmemiş, çok az sayıda Uluslararası İlişkiler çalışanı bu temassızlığı ancak 1980'lerden itibaren fark ederek belirtmiştir. ${ }^{2}$

Bu makalenin birinci argümanı, Uluslararası İlişkiler disiplininin Marksizm’i dışarıda tutmaya çalışması kadar, Marksist düşünce geleneğinin de hem ontolojik olarak uluslararası ilişkilere, hem de bir çalışma alanı olarak Uluslararası İlişkiler disiplinine en azından mesafeli durduğu, bunun da Marksizm'in niteliğinden kaynaklanan nedenleri olduğudur. İkinci argüman, Uluslararası İlişkilerin Ortodoks Marksizm'i aşağıda ele alınacak nedenler yüzünden alanın dışında tuttuğu ama 1980'lerde Soğuk Savaşın etkisinin azalmasıyla birlikte kabul ettiği kadarını da disipline ancak dönüştürerek dahil ettiği ve hakim Uluslararası İlişkiler mantığına ve kurgusuna uygun bir hale getirdiğidir. Üçüncü argüman ise, disiplinde bir Anglosakson (İngilizce konuşan) ülkeler hakimiyetinden söz edilse de, ${ }^{3}$ alanın gelişimini ABD kökenli yazar ve tartışmaların belirlediği saptamasından yola çıkarak, özellikle Marksizm'i dışlama çabasının ABD kaynaklı olduğu; İngiltere, Kanada ve Avustralya kökenli yazarların 1980'lerden başlayarak ve özellikle 1990'lardan itibaren geç ve sınırlı düzeyde de olsa Marksizm ile diyaloğa girdikleridir. Bu bağlamda, İngiltere özelinde Marksizm ile kurulan bu diyalog ve tartışmanın nedenleri, gelişimi ve Uluslararası İlişkiler disiplini açısından yarattığı sonuçlar da ele alınacaktır.

Argümanları temellendirmeye geçmeden önce, makalenin sınırlarına da dikkat çekmek gereklidir. Öncelikle, bu yazı, özellikle Türkçe literatür için Marksizm ve Uluslararası İlişkiler disiplini arasındaki ilişkiyi tanıtıcı bir giriş yazısıdır. Bu bağlamda, eleştirel literatür değerlendirmesi yaparken, mevcut durumu tarifleyebilmek için bir fotoğraf çekmeye ve bu fotoğraftaki öğelerin neden

1 Literatürdeki yaygın kullanıma uygun olarak, disiplinden bahsettiğimizde büyük harflerle, araştırma nesnesinden ya da analiz biriminden bahsettiğimizde ise küçük harflerle "uluslararası ilişkiler" terimini kullanıyoruz.

2 Hazel Smith, "Silence of the Academics: International Social Theory, Historical Materialism and Political Values", Review of International Studies, Cilt 22, No. 2, Nisan 1996, s.202.

3 Kalevi Holsti, The Dividing Discipline, Hegemony and Diversity in International Theory, Londra, Allen \& Unwin, 1985. 
halihazırdaki konumlarında olduklarını anlayabilmek için arkalarındaki süreçler ve ilişkisellik incelenmeye çalışılmıştır. Makalenin bir diğer sınırı ise, konuya Batı Marksizmi açısından yaklaşmasıdır. Marksizm Batı'da ortaya çıkmış bir akım ve kuram olarak homojen ve tek bir yoruma dayalı bir sosyal teori olmaktan ziyade, tarihsel süreç içinde farklı şekillerde yorumlanarak ortodoks Marksizm, Yapısalcı Marksizm, Siyasal Marksizm, Açık Marksizm gibi örnekler alarak çeşitlenmeye devam etmektedir. Bu kuramsal çeşitliliğin yanında, Marksizm’in tarihi uygulamayla iç içe ve devlet ideolojisi olarak "resmi” Marksizmler de üretmiştir. Bu makalede, bu tür resmi Marksizm ve onun Uluslararası İlişkilerle kurduğu ilişkiler dışarıda bırakılmıştır. Aynı şekilde Uluslararası İlişkiler de Batı akademisindeki hâkim formları üzerinden ele alınmıştır. Bu çerçevede, makalenin ilk kısmında Uluslararası İlişkilerin tarihsel gelişimi içinde bir dışlama pratiği olarak Marksizm’le ilişkisi incelenirken, makalenin geri kalanında Uluslararası İlişkiler ve Marksizm arasındaki mevcut ve olası bağlar hem Marksizm perspektifinden hem de tarihsel materyalist Uluslararası İlişkiler yazarları açısından değerlendirilmiştir.

\section{Bir Dışlama Pratiği Olarak Uluslararası İlişkiler Disiplini ve Marksizm}

Marksizm'in metodolojik ve epistemolojik açıdan Uluslararası İlişkiler alanının dışında tutulması, disiplinin kuruluş aşamasında başlar. Literatürde yerleşmiş olan disiplinin kuruluş aşamasında "idealist" bir anlayışın öne çıktığı görüşü artık tartışılıyor ve yeniden yazılıyor. ${ }^{4}$

Öncelikle, bu dönemde kendilerini idealist olarak tanımlayan bir Uluslararası İlişkiler akademik camiası bulunmadığı bilinmektedir. ${ }^{5}$ Kıta Avrupasında bu türden bir akım ve tartışma olmadığı göz önüne alındığında, ABD’li ve İngiliz bazı düşünürlerin savaş olgusu ve barışın tesisi konusundaki entelektüel tartışmalarının dar bir çevreyle sınırlı olduğu anlaşılır. Bunlar içinde ABD'de James Shotwell, Edwin Ginn, Woodrow Wilson, İngiltere'de Norman Angell, Alfred Zimmern gibi isimler öne çıkarlar. Bilimsel sınırları, metodolojisi, aynı ortak dili ve kavramları paylaşan, bütüncül bir araştırma programına sahip olmayan bu dağınık fikirsel üretim süreci akademik olmaktan çok politik bir içerik taşır. Bir defa bu yazarların önemli bir kısmı ABD hâkim sınıflarının içinden gelmektedir; kimisi işadamı (örneğin Ginn) kimisi uluslararası kuruluş ve baskı grubunun üyeleridir (örneğin Shotwell), kimisi de akademik olmaktan çok siyasi kimliğiyle öne çıkar (örneğin Wilson). ABD’de bir yandan da Rockefeller Vakfı 1923'ten itibaren Sosyal Bilimler Araştırma Konseyi’ni (Social Science Research Council) kurarak Uluslararası İlişkiler çalışmalarını fonlamaya başlamış, işadamlarının kurduğu Brookings ve Carnegie gibi düşünce kuruluşları ile Amerikan hâkim sınıflarının önde gelen kuruluşu Council on Foreign Relations yine bu dönemde Uluslararası İlişkilerin gelişiminde önemli rol oynamıştır. Dolayısıyla disiplinin kuruluşu, önde gelen akademisyenleri, finansmanı ve kurumsallaşması açısından belirgin bir sınıfsal nitelik göze çarpar. ${ }^{6}$

4 Bkz. Miles Kahler, "Inventing International Relations: IR Theory after 1945," Michael Doyle ve John Ikenberry (der.), New Thinking in IR Theory, Oxford, Westview Press, 1997, s. 20-53.

5 Atila Eralp (der.), Devlet, Sistem, Kimlik, İstanbul, İletişim,1996, s. 57-88.

6 Aynı dönemde İngiltere'de sivrilen Norman Angell ve Alfred Zimmern gibi isimler bir tür liberal enternasyonalizm fikrine yakın dururlar, fakat ikisi de hem siyasetle iç içedir (Angell milletvekili olacak, Zimmern Versay heyetinde yer alacak ve başbakan adayı olacaktır) ve ABD bağlantıları güçlü isimlerdir. Bkz. Martin Griffiths, Fifty Key Thinkers in International Relations, Londra, Routledge, 1999, s. 100-101, 104; Paul Rich, "Reinventing Peace: David Davies, Alfred Zimmern and Liberal Internationalism in Interwar Britain”, International Relations, Cilt 16, No. 2, Nisan 2002, s. 117-133. 
Bunun önemi, diğer sosyal bilim disiplinlerinden farklı olarak Uluslararası İlişkilerin doğrudan belli bir hâkim sınıfın politik kurgusu olarak gelişmeye başlamış olmasıdır. Kıta Avrupası geleneğinden gelen diğer sosyal bilim dallarında aydınlanma ve sanayileşme olguları önemli bir yer tutarken, Anglosakson coğrafyası içinde kalan Uluslararası İlişkiler daha en başında savaş/barış tartışmasına odaklanmış, Birinci Dünya Savaşı sonrasında örgütlenme fikirleri ve savaşın nasıl önlenebileceği tartışması öne çıkmıştır.

Uluslararası İlişkilerin yerleşik bir disiplin haline geldiği İkinci Dünya Savaşı sonrası dönemde ise disiplin bu kez devlet merkezli ve güvenlik odaklı olarak Soğuk Savaş koşullarını yansıtan bir içerikle ve ABD'nin hegemonik konumuna uygun bir şekilde yeniden tanımlanmıştır. ${ }^{7} \mathrm{Bu}$ dönemde ağırlıklı olarak Almanya'dan göç etmiş olan Hans Morgenthau, Arnold Wolfers, John Herz, Henry Kissinger ve ABD kökenli Reinhold Neihbur, George Kennan gibi isimlerin öne çıktığı ve siyasetin merkezinde ideolojik olarak komünizm ile politik ve stratejik olarak Sovyet karşıtlı̆̆ının bulunduğu, bunun bütün epistemolojiyi belirlediği bir akademik yazım süreci başlamıştır. Bundan sonra disiplinin gelişimi ve ana tartışmaları ABD eksenli yürütülecek, takip eden yaklaşık elli yıllık dönemde Gerçekçilik ve onun kavramları, metodolojisi (bazen geleneksel bazen davranışsalcı yöntemlerle) disiplinde merkezi bir yere sahip olacaktır. Marksizm’e (ve Leninizm’e) ait bazı kavramlar ancak kısaca eleştiriye tabi tutulmak ve yanlışlanmak için alınacaktır. Örneğin, Morgenthau emperyalizmi "statükoyu bozmaya yönelik dış politika eylemleri” olarak tanımlayacak, ABD dış politika eylemlerini değil, onun hegemonyasında kurulan düzeni değiştirmeye yönelik girişimleri emperyalizm olarak ilan edecektir. ${ }^{8}$

Henüz Yapısalcı Gerçekçilik kuramını ortaya atmadan önce Kenneth Waltz da Marksizm’i, tartıştığı üç görünüm -insan, devlet ve savaş- içinde ikinci görünüme (second image) yerleştirir. Ona göre Marksizm çatışma ve savaşın nedenlerini devletlerin iç yapısında görür ve bu nedenle ikinci görünümde yer alır. Waltz bununla da kalmaz ve Marksizm'in, sınıfsız toplumla birlikte savaşın sona ereceği öngörüsünü ironik bir şekilde eleştirerek, savaşların sona ermesi için “önce devletlerin mi yoksa kapitalizmin mi sona ermesi gerektiği”ni sorar. ${ }^{9}$ Oysa bu sorunun yanıtı herhangi bir Marksizm'e giriş kitabında açıkça yer alır. Marx ve Engels savaş ve çatışmaların nedenlerinin hasmane sınıfların mücadelesinde yattığını iddia etmişlerdir. Kapitalizmin ortadan kalkması ve sınıfsız topluma geçilmesi, beraberinde devletin ve çatışmaların ortadan kalkmasını sağlayacaktır. Waltz literatürde iz bırakan bu göndermesinin ötesinde Uluslararası İlişkiler disiplininin en çok atıf yapılan çalışması olan The Theory of International Politics kitabında emperyalizme çok daha geniş bir yer ayırarak, emperyalizm kuramını bu kez indirgemeci, çelişkili ve açıklama gücünden yoksun bir yaklaşım olarak tanımlar. Bütün kapitalist ülkelerin emperyalist olmadığı, emperyalizmin (sonuç) kapitalizmden (neden) nasıl olup da daha eski olabildiği gibi sorular sorarak, Lenin ve benzer şekilde Hobson'u yanlışlamaya çalışır. ${ }^{10}$

1950’lerden itibaren bir yanda analiz düzeyi tartışması, öte yanda davranışsalcı yaklaşımla birlikte disiplinde geniş yer tutmaya başlayan Sistem Analizleri, Karar Verme Kuramları, Oyun Kuramı, niceliksel çalışmalar ve literatürde "ikinci büyük tartışma” olarak geçen davranışsalcı-gelenekselci ayrımı, alanı tarihsellikten ve sosyolojik boyuttan daha da kopardı. Genel olarak sosyal bilimlerin değer yargısından bağımsız olması gerektiği fikri ABD’de Daniel Bell, Edward Shils, Talcott Parsons gibi

7 Bu tartışma için bkz. Steve Smith, "The United States and the Discipline of International Relations: Hegemonic Country Hegemonic Discipline”, International Studies Review, Cilt 4, No. 2, Yaz 2002, s. 67-85.

8 Hans Morgenthau, Politics Among Nations: The Struggle for Power and Peace, New York, Knopf, 1967, s. 27-28.

9 Kenneth Waltz, Man, the State and War, New York, Columbia University Press, 1954, s. 125, 127.

10 Kenneth Waltz, The Theory of International Politics, Reading-MA, Addison-Wesley Pub., 1979, s.28-35. 
sosyologlar tarafından dile getirilirken, ${ }^{11}$ Uluslararası İlişkiler içinde de davranışsalcı akım ideolojiyi bilimin karşısına yerleştirdi. Burada aslında ideolojiden kastedilen Marksizm’di. Batı sistemi ideali ve normatif olarak doğru olanı temsil ettiği için, onun dışında kalan Marksizm ideolojik olarak tanımlandı ve ideolojik olduğu için de geçerli bir bilimsel yöntem olarak görülemeyeceği vurgulandı.

Gerçekten de davranışsalcı akımla birlikte normatif bir niteliği olmayan, değer yargısı taşımayan, siyasal olmayan, faydacı özellikler taşıyan ve dolayısıyla Marksist kavramlara ve yönteme çok uzak duran bir disiplin gelişimi söz konusuydu. Örneğin, David Singer analiz düzeylerini tanımladığı klasikleşmiş çalışmasında uluslararası sistemi ve devletleri analiz düzeyi olarak belirlerken, dönemin ruhuna uygun olarak sınıf kavramına hiç değinmedi. ${ }^{12}$ Yine, Karar Verme yaklaşım ve modellerinde rasyonelbilişsel tartışması ve ikiliği üzerinden analizler yapılırken, dönemin Sovyet ve ABD karar vericilerinin ve karar verme birimlerinin özellikleri pozitivist metodoloji çerçevesinde mekanik olarak ele alındı.

Aynı dönemde ikinci tartışmada, gelenekselci tarafta duran İngiltere’de oluşmaya başlayan “İngiliz Okulu” geleneği, son tahlilde pozitivizmin etkisi altında 1980’lere kadar uluslararası ilişkileri anlamak için Batı değer ve normlarının yayılmasını öngören bir "uluslararası toplum” fikrinden hareket ediyordu. Kıta Avrupasında ise felsefe geleneğinin güçlü olduğu Almanya, Fransa, İtalya, Hollanda gibi ülkelerin akademisyenleri genelde Uluslararası İlişkiler disiplininin dışında kalırken, Fransa'da politik olarak Sovyet ve Marksizm karşıtı Raymond Aron'un Gerçekçilik temelli Barış ve Savaş başlıklı çalışması, İngilizceye çevrilerek bir istisna oluşturdu. ${ }^{13}$

Uluslararası İlişkiler disiplininde 1970’lerden itibaren merkezinde (yeni)liberal yaklaşımların bulunduğu çoğulcu (pluralist) döneme geçildiğinde de ana akım literatürün Marksizm’e yaklaşımı büyük bir farklılık göstermedi. Bu çoğulculuğun içinde Gerçekçilik/Yeni-Gerçekçilik, Liberalizm/Globalizm ve Yeni-Marksizm/Yapısalcılık yer alıyordu. ${ }^{14}$ "Paradigmalar arası tartışma" olarak da anılan bu dönemde, Marksizm yapısalcı bir kimlikle ele alınıyor ve eşit statüde bir yaklaşım gibi görülüyordu. Fakat, disiplinin sonraki gelişim sürecinde bu eşit statü kalıcı olmadı.

Çoğulcu olarak adlandırılan bu dönemde Yeni-Liberal yaklaşımın, Avrupa Birliği (AB) entegrasyon sürecinden kaynaklanan Bütünleşme Teorileri, (Yeni) Kurumsalcılık, Karşılıklı Bağımlılık, Rejim Teorisi gibi versiyonları ve devlet dışı aktörlerin öneminin artmasının yarattığı küresel dönüşümler gibi temalar disiplin içinde ele alınmaya başlandı. Disiplindeki metodolojik ve kavramsal çoğulculuktan söz edilirken ve disiplin dışında Yeni-Marksist emperyalizm kuramları, Bağımlılık Okulu ve Dünya Sistemi Yaklaşımı gelişirken, bu makalede ileri sürülen argümana uygun olarak "üçüncü tartışma” Marksizm'den esinlenen yaklaşımlarla değil, Yeni-Gerçekçilik ile yürütüldü. ${ }^{15}$ Diğer bir deyişle, literatür liberalizmin karşıtının Marksizm değil Gerçekçilik olduğunu vurgulayarak, Marksizm’den kaynaklanan yaklaşımları özenle kendisinden uzak tuttu. Merkez-çevre, artığın emilmesi, eşitsiz mübadele gibi kavramlar o dönemde herhangi bir şekilde disipline yansımadı. Dahası, ana akım literatür Keohane ve Nye'ın Yeni-Liberal "Karşılıklı Bağımlılık” kuramından hareketle uluslararası sistemi, kuzey-güney arasındaki eşitsizlik ve bağımlılık üzerinden değil, çoklu bağlarla birbirine geçmiş bir karşı-

11 Bkz. Nils Gilman, Mandarins of the Future, Baltimore, Johns Hopkins University Press, 2003, s.47-58.

12 David Singer, “The Level of Analysis in International Relations," World Politics, Cilt 14, No. 1, Ekim 1961, s.77-92.

13 Raymond Aron, Peace and War: A Theory of International Relations, New York, Doubleday \& Company, 1966.

14 Paul Viotti ve Mark Kauppi, International Relations Theory, New York, MacMillan, 1993.

15 Bu tartışma için bkz. Charles Kegley (der.), Controversies in International Relations: Realism and the Neoliberal Challenge, New York, St. Martin's Press, 1995; David Baldwin (der.), Neorealism and Neoliberalism: The Contemporary Debate, New York, Columbia University Press, 1993. 
lıklı karmaşık bağımlılık ilişkisiyle tanımlamayı tercih etti. ${ }^{16}$ Yeni-Liberal yaklaşımın önde gelen isimlerinden Robert Keohane de ses getiren After Hegemony çalışmasında Marksizm ve emperyalizm kuramlarıyla diyalog kurmakla birlikte, daha çok Marksizm'deki yetersizlik ve çelişkiler üzerinde durdu. ${ }^{17}$

Disiplinde Yeni-Liberal yaklaşım ekonomik faktörlere önem vermekle birlikte, vurgusu üretim değil ticaretti ve kapitalist üretim ilişkilerini incelemek yerine ticaretin siyasal sonuçlarına -entegrasyon, rejimler, demokratik barış gibi- odaklanıyordu. Sonuçta, Ole Weaver'ın da belirttiği gibi YeniGerçekçilik, Yeni-Liberalizm'e rakip değil, onu tamamlayan ve sentez oluşturan bir yaklaşım oldu. ${ }^{18}$

Bu durum, Soğuk Savaş koşullarında ABD merkezli Uluslararası İlişkiler disiplininde tarih ve ekonomi dışı, toplumu ve modernleşmeyi analiz dışında tutan, özcü, pozitivist, statükocu ve devlet merkezli, devletin güvenliğini öne çıkaran bir yaklaşım geliştirdi ki bu unsurların hemen hepsi Marksizm karşıtıdır. Alan içinde geliştirilen kuram ve yaklaşımların yalnızca ideolojik olmadığı değil, olmaması gerektiği vurgulandı ve yoğun bir objektiflik iddiasına dayanmaya çalışıldı. Moral değerlere başvurulduğunda ise Reinhold Niebuhr’a dayanarak, insandaki kötülügü ilk günaha götüren Hiristiyan inancına giderek, hem Batı merkezli, hem de muhafazakâr bir temele oturuldu. ${ }^{19}$

Dönem olarak 1980’lerin ortalarına kadar, coğrafi olarak da ABD ve bir ölçüde İngiltere'de ama sonuçta Batı sistemi içindeki ülkelerde Uluslararası İlişkiler çalışmalarında benimsenen bu yaklaşım temel analiz çerçevesini oluşturdu. Burada temel mesele siyaseti analiz etmek değil, Batı sistemindeki devletin ve dolayısıyla mevcut siyasal-ekonomik düzenin nasıl ayakta kalacağını ve gücünü nasıl koruyacağını tartışmaktı. Kısacası bu kuruluş ve gelişim döneminde disiplin Soğuk Savaş siyasetinin akademik bir uzantısı olarak kaldı. Fakat aşağıda da ele alınacağı gibi, ABD özelinde bu durum, Soğuk Savaş sonrasında da çok az değişime uğrayarak devam etti.

Soğuk Savaş'ın sona ermesi ve Batı sisteminin bu yükten kurtulması, artık Marksizm’in ve ondan esinlenilen kavramların daha rahat ve daha yaygın kullanılmasını sağladıysa da, bu dönemde de disiplinin eski metodolojik sorunları devam etti ve alternatif perspektifleri dışarıda bırakan ikilikler bu dönemde yeniden kuruldu. 1980'lerin sonundan itibaren alanda pozitivizm-postpozitivizm, rasyonel-yansıtmacı (reflectivist), açıklayıcı-oluşturucu (explanatory-constitutive) gibi başlıklar altında yeni bir tartışmalar başladı. ${ }^{20}$ Disiplinin pozitivist ve devlet merkezli kurgusu Marksizm’i 1945 sonrasında dışarıda bırakırken, 1990 sonrasındaki postpozitivist, postyapısalcı ve postmodern, toplum temelli yeni kurgusu bu kez de söylem, kültür, kimlik gibi fikirsel (ideational) unsurlar üzerinden disiplini tanımlayarak Marksizm'e alan açmadı.

Uluslararası İlişkilerin son “büyük teorisi” olarak görülen Toplumsal İnşacılık da, toplumsal normlar ve fikirsel etkenleri temel alarak, materyalist yaklaşımlarla tartışmaya girer. Bu yaklaşımın önde gelen isimlerinden Alexander Wendt disiplinin organik kuramları olan Gerçekçilik/Yeni-Gerçekçilik ve Yeni-Liberalizm'le tartışmayı merkeze alır ve geçerken materyalist doğası nedeniyle Marksizm’i de eleştirir. Wendt, “üretim ilişkilerinin tamamıyla fikirsel bir fenomen” olduğunu belirterek, ${ }^{21}$ kurallar ve kurumların paylaşılan fikirlerle oluştuğunu ve bunların mülkiyet ve değişim ilişkilerini oluşturduğunu

16 Robert Keohane ve Joseph Nye, Power and Interdependence, Boston, Little Brown, 1977.

17 Robert Keohane, After Hegemony, New Jersey, Princeton University Press, 1984.

18 Ole Waever, “The Rise and Fall of the Inter-paradigm Debate," Steve Smith vd. (der.), International Theory: Positivism and Beyond, Cambridge, Cambridge University Press, 1996.

19 Reinhold Niebhur, Moral Man and Immoral Society, Kentucky, John Knox Press, (1932)1960.

20 Bkz. Peter Katzenstein, Robert Keohane ve Stephen Krasner, "International Organization and the Study of World Politics," International Organization, Cilt 52, 1998, s. 646.

21 Alexander Wendt, The Social Theory of International Politics, Cambridge, Cambridge University Press, 1999, s.90. 
ileri sürer. İlginç biçimde, Marksist literatürden hiçbir kaynağa atıf yapmayan Wendt, aslında çok açık görünen materyalist açıklamaların içlerinde bastırılmış inşacı iddialar taşıdığını, ayrıca kapitalizmin materyalist değil, ağırlıklı olarak kültürel bir form olduğunu, çünkü Marksizm'in maddi alt yapısının fikirlerden oluştuğunu savunarak maddi gerçekliği fikir düzlemine indirger. ${ }^{22}$

İnşacilık Marksizm'in en temel ontolojisi olan materyalizmi birkaç cümleyle norm ve kültüre dönüştürürken, Uluslararası İlişkiler içinde Postmodern/postyapısalcı bakışın temsilcileri olan James Der Derian, R.J.B. Walker, Richard Ashley, Michael Shapiro gibi isimler disiplin içinde marjinal, s1nırda, sürgün ve muhalif konumda olduklarını dile getiriyorlardı. ${ }^{23}$ Ama aslında postmodern düşünce de, gerek gerçekliğin objektif değil öznel olduğu ve dil ile kurulduğu yorumuyla uluslararası ilişkileri metinlerarası ilişkilere ${ }^{24}$ (intertextual relations) indirgeyerek, gerekse kültürel göreceliği öne çıkararak, bir "büyük anlatı" (meta-narrative) olan Marksizm'in alanın dışında kalmasına katkıda bulundu.

Dolayısıyla, Uluslararası İlişkiler disiplini 1980’lerden itibaren yaşanan gevşemeye kadar Marksizm’i dışarıda tutup, onu yalnızca eleştiriye tabi tutulması gereken, metodolojik anlamda açıkça dile getirmediği bir öteki olarak gören ama herhangi bir tartışmanın tarafı olarak meşruiyet yüklenmeyen, kendi içinde bir alan olarak gördü. Ana akım Uluslararası İlişkilerin Marksizm’e yönelttiği eleştiriler birkaç noktada toplanabilir: En yaygın eleştiri, mevcut devletler sisteminin kendisinin Marksizm için bir sorun oluşturduğu ve Marksizm' in bunu açıklayamadığıdır. ${ }^{25}$ Marx’’n bir devlet teorisi geliştiremediği, özellikle savaş, çatışma ve milliyetçilik gibi konularda zayıf kaldığı ileri sürülür. Artı değer, işbölümü gibi kavramların ise uluslararası ilişkilerle bağlantılı olmadığı bu eleştiriler arasındadır. ${ }^{26}$

Marx ve Engels' in doğrudan bir uluslararası ilişkiler kuramı geliştirmedikleri doğrudur; fakat Birinci Dünya Savaşı öncesi dönemde hiçbir yazar disiplinin tariflediği şekilde bir uluslararası ilişkiler kuramı oluşturmamıştı. Bu açıdan nasıl ki Makyavel, Locke, Hobbes, Adam Smith ve Kant kendilerinden sonra gelişen disiplinin içindeki bazı kuram ve yaklaşımların kaynağı oldularsa, Marksizm bunun daha da ötesinde bir toplum, ekonomi ve tarih perspektifi çizerek ekonominin ve siyasetin nasıl inceleneceğini, yeni bir toplum düzeninin nasıl kurulacağını ve son noktada insanın özgürleşmesi sorunsalını analizinin merkezine alarak alternatif bir paradigma önermiştir.

Diğer bir eleştiri, Marksizm'in “işçi sınıfının ulusu olmadığı” iddiasının yanlışlandığı, milliyetçilik olgusunun etkisini hesaba katamadığı, ${ }^{27}$ "dünyanın bütün işçilerinin birleşmediği," aksine kendi ulus devlet sınırları içinde hareket ettikleri görüşüdür. ${ }^{28}$ Marksist yaklaşım, iddia edilenin aksine milliyetçilik konusunda belli bir teze sahiptir ve milliyetçiliğin ortaya çıkış dinamiklerini inceler. Ayrıca, işçi sınıfının milliyetçi eğilimler göstermesi de Birinci Dünya Savaşı’ndan beri Marksist düşünür ve yazarları pratik ve teorik düzlemde düşündüren bir çelişkidir ve bu tavrın nedenleri Marksist literatür-

22 Wendt, The Social Theory, s.94.

23 Richard K. Ashley ve R. B. J. Walker, “Speaking the Language of Exile: Dissidence in International Studies,” International Studies Quarterly, Cilt 34, No. 3, Eylül 1990, s. 259-268.

24 James der Derian ve Michael Shapiro (der.), International/Intertextual Relations: Postmodern Readings of World Politics, New York, Lexington Books, 1989; Peter Evans, Dependent Development, Princeton, Princeton University Press, 1979.

25 Bkz. R. N. Berki, “On Marxian Thought and the Problem of International Relations," World Politics, Ekim 1971, s. 80105.

26 John Maclean, "Marxism and International Relations: A Strange Case of Mutual Neglect”, Millennium, Cilt 17, No. 2, Haziran 1988, s. 297.

27 Andrew Linklater, “Marxism," Scott Burchill vd., Theories of International Relations, 3. Baskı, Londra, Palgrave, 2006, s. 111. Ayrica bkz. Erica L Benner, "Marx and Engels on Nationalism and National Identity: A Reappraisal”, Millennium, Cilt 17, No. 1, 1988, s. 10.

28 Efraim Nimni, Marxism and Nationalism, Londra, Pluto Press, 1991. 
de tartış1lır. ${ }^{29}$ Öte yandan, Marksizm'in bir bilimsel yöntem olarak dünya tarihinin, toplum ve siyasetin her noktasını açıklamasını, bütün öngörülerinin doğru çıkmasını beklemek, ona bilim dışı bir anlam yükler. Dolayısıyla, tarihsel süreçte Marksizm' in bazı öngörülerinin gerçekleşmemesi, bazı toplumsal/ siyasal süreçleri açıklamakta zorlanması, bilimsel niteliğinin bir sonucu olarak görülebilir.

Soğuk Savaş koşullarında anlaşılır olan bu dışlama, ortaklık kurmaktan kaçınma ve içeriye almadan eleştirme pratikleri, Doğu Bloku yıkıldıktan sonra da özellikle Amerikan Uluslararası İlişkiler çevrelerinde devam etmiştir. ABD kaynaklı Uluslararası İlişkiler genel olarak her biri Marksist kavram ve metodolojiyi tamamen dışarıda bırakan üç akım üzerinden gelişti: Bunlar Gerçekçilik ve versiyonları, pozitivist/niceliksel çalışmalar ve postpozitivist/İnşacı yaklaşımlar olarak ABD akademik dünyasını domine etmeyi sürdürdü. ${ }^{30} \mathrm{Bu}$ da bize meselenin yalnızca Soğuk Savaş bağlamıyla sınırlı olmadığını, küresel sistemin kurulu düzeniyle ilişkili bir bilgi üretim sürecinin parçası olduğunu ve o düzenin hegemonik disiplini olan Uluslararası İlişkilerin tıpkı Soğuk Savaş sona erince Amerikan hegemonyasının sona ermemesi, NATO'nun dağılmaması hatta daha da genişlemesi gibi, disiplin olarak Marksizm'le kurduğu ilişkide de radikal bir değişikliğe gitmediğini gösterir. Tersine, reel sosyalizmin çökmesinin getirdiği prestij kaybı ve liberalizmin zaferini ilan etmesiyle, örneğin eski Doğu Avrupa'ya tıpkı geçiş dönemi süreçlerinde yeni-liberalizm ve siyasal çoğulculuğun yayılması gibi, Batı sosyal bilim geleneğiyle birlikte ABD merkezli Uluslararası İlişkiler teorileri de yeni bölgelerde yayılma imkânı buldu. Buna bir de küreselleşme süreciyle iletişim imkânlarındaki artış eklenince Batı ve ABD merkezli Uluslararası İlişkiler teorileri Soğuk Savaş sonrasında hegemonik gücünü artırdı. Sonuç olarak, Uluslararası İlişkiler disiplini alternatif perspektifleri dışarıda tutan bir anlayışla Batı sosyal bilim dalları içinde belki de en muhafazakar akademik alanlardan biri olarak kurulmuştu ve Soğuk Savaş bitince en azından ABD'deki ayağında bu açıdan büyük bir değişiklik yaşanmadı.

\section{Marksizm, Uluslararası İlişkiler ve Emperyalizm}

Ana akım Uluslararası İlişkilerin kurmaya çalıştı̆̆ dünya algısıyla Marksizm’in tahayyülleri neredeyse taban tabana zıttır. Marksizm'de kuram ve yöntem ile teori ve pratik analitik olarak birbirlerinden ayrı düzlemlerde düşünülemez, yöntem ve kuramın içeriği karşılıklı olarak birbirlerini belirler. Marksizm'in dünyayı anlama yönünde ortaya koyduğu devrim niteliğindeki değişiklik, sosyal kuramı tarihsel materyalizm üzerine kurması ve bunu da diyalektik bir yöntemle yapmasıdır. Marksizm, idealist felsefi ön kabullerden yola çıkılarak oluşturulmuş kavramların karşısına, maddi koşullardan kaynaklanan öncüllere dayalı soyutlamaları koyar. ${ }^{31}$ Marksizm'in kavramları ve olguları ilişkisellik içinde ele alabilmesinin ön koşulu, toplumsal olanı bütünsellik ${ }^{32}$ içinde kavrayabilmesidir. Marksizm, toplumsal dünyanın analitik olarak ayrıştırılarak, farklı disiplinlerin konularıymış gibi bölünerek ve yalıtılarak anlatılmasına karşı çıkar. ${ }^{33}$ Uluslararası İlişkilerin analizine başlangıç noktası tekil birimler olarak devletler ve bu devletlerin arasındaki ilişkiler iken, yani esas olarak parçalar arasındaki ilişkiler

29 Örneğin bkz. Michael Forman, Nationalism and the International Labor Movement, University Park PA, Penn State University, 1998.

$30 \mathrm{Bu}$ konuda hem Steve Smith'in hem de Ola Waever'in ampirik verilerle desteklenen çalışmaları ABD Uluslararası İlişkiler çalışmalarındaki bu eğilimleri net olarak gösterir. Steve Smith, "The United States and the Discipline of International Relations", s.79-82; Ole Waever, "The Sociology of a Not So International Discipline: American and European Developments in International Relations”, International Organization, Cilt 52, 1998, s.687-727.

31 Karl Marx and Friedrich Engels, The German Ideology, International Publishers Co, 1970.

32 György Lukács, History and Class Consciousness: Studies in Marxist Dialectics, Cambridge MA, MIT Press, 1971.

33 Alexander Anievas (der.), Marxism and World Politics: Contesting Global Capitalism, New York, Routledge, 2010. 
iken, Marksizm genel bir bütünsellik içinde yapıyı tanımlar ve bu yapı içindeki birimlerin tarihsel kategoriler oldukları bilinciyle birbirleri ve bütün ile olan ilişkilerine bakar. ${ }^{34}$

Lenin'in Emperyalizm kitabıyla birlikte Marksizm’i Uluslararası İlişkiler bağlamında düşünmek, onu bir şekilde emperyalizm kavramına eşitlemek anlamına gelmiştir. Neredeyse son yüz yıldır hem Batı'daki Marksist gelenek, hem de Sovyet politik deneyimi, uluslararası ilişkiler ve dış politika dendiğinde emperyalizm kavramını hem bir siyaseti tanımlama anlamında pejoratif olarak kullandı, hem de Batılı ülkelerin dış politikalarını analiz etmede bir kuramsal çerçeve olarak ele aldı. Gerçekten de Marksizm'in Uluslararası İlişkilere olumlu ya da olumsuz bir katkısı varsa, o da emperyalizm kuramıdır ve daha önce görüldüğü gibi, ana akım literatür de Uluslararası İlişkilerde Marksizm’i emperyalizm kuramı olarak ele almıştır.

Kökenlerine ve gelişimine bakıldığında emperyalizmin son yüzyıl içinde çeşitli evrelerden geçtiği görülür. Öncelikle, Marx’ın emperyalizm kavramını kullanmadığı, kolonyalizmin farkında olduğu ve özellikle İngiltere’nin Hindistan'daki koloni yönetimiyle ilgili olarak yazdıklarının bu konudaki literatür için önemli bir yer tuttuğunu belirtmek gerekir. Gerçekten de, Marx, The New York Tribune gazetesine yazdığı makalede daha sonraki Yeni-Marksistlerden farklı olarak kapitalizmin geri bölgelere yayılmasının dönüştürücü etkilerinden söz eder. Ona göre kapitalizm azgelişmiş bölgelere yayılırken iki boyutta dönüştürücü olur: Bir taraftan eski olan kurumları ve geleneksel yapıyı yıkarken, öte yandan geleneksel üretim ilişkilerini dönüştürür ve yenisini kurar. Marx’ın kuramında kapitalizm feodalizmden daha ileri bir aşamayı temsil eder. Marx, İngiliz koloni yönetiminin yarattığı yıkımı sert bir dille eleştirmekle birlikte, koloni toplumları için de "yarı barbar" gibi ifadeler kullanır ve bunun bir uzantısı olarak, kapitalizmin girdiği yerdeki dönüştürücü rolünü tespit eder. Dolayısıyla, emperyalizm kavramını kullanmadan, kapitalizmin kolonilere yayılmasını sosyalizme geçiş aşamasında zorunlu bir uğrak olarak değerlendirir. ${ }^{35}$ Marx doğrudan emperyalizm kuramı geliştirmemişse de, hem çeşitli yazılarında, hem de günümüzde artık küreselleşme olgusunun da ilk tespit edildiği metinlerden biri olarak Komünist Manifesto'da kapitalizmin bu dünyanın her köşesine yayılma eğilimini ve bu süreçte kendi üretim tarzını dayatmaya çalıştığını belirterek, ${ }^{36}$ burjuvazinin bütün dünyada kendi görünümünü yaratacağını erken bir tarihte tespit etmiştir.

Genel olarak Marksizm’e göre tarihin motoru olan sınıf çatışması kapitalist toplumda iki düzlemde gerçekleşir. İlki, tahmin edilebileceği gibi, burjuvazi ile işçi sınıfı arasındaki hasmane ilişkiden doğan mücadeledir. İkinci düzlem ise, bir ülkedeki burjuvazinin rakip başka ülke burjuvazileriyle girdiği mücadeledir ki, emperyalizm teorisi de buradan doğar. ${ }^{37}$

19. yüzyıl sonunda emperyalizmi analiz edenler tahmin edilebileceği gibi, yaşadıkları dönemde sermayenin gelişimine ve kapitalist devletler arasındaki ilişkilere yoğunlaşmışlardır. Klasik emperyalizm dönemi olarak da adlandırılan (kabaca 1870-1914 arası dönem) sanayi kapitalizminin getirdiği imkânlarla kolonizasyon sürecine başlayan ve merkezi kapitalist ülkeler arasında büyük bir savaşa yol

34 Fakat bu, Marksizm’in uluslararası ilişkilerin farklı görünümlerini göz ardı ettiği anlamına gelmez. Marx, burjuva ekonomisini sırasıyla sermaye, toprak mülkiyeti, ücretli emek, devlet, dış ticaret ve dünya piyasası üzerinden incelediğini söyler. Bkz. Karl Marx, A Contribution to the Critique of Political Economy, New York, International Publishers, 1970. Uluslararası ilişki formu, öncelikle uluslararası ticaret ve dolayısıyla uluslararası ödemeler dengesidir. Bkz. Karl Marx, Capital: A Critique of Political Economy, Cilt 1, New York, Penguin Books, 1976

35 Karl Marx, “The British Rule in India," The New York Daily Tribune, 25 Haziran 1853. <http://www.marxists.org/ archive/marx/works/1853/06/25.htm.

36 Karl Marx and Friedrich Engels, The Communist Manifesto, Echo Library, 2009.

37 Anthony Brewer, Marxist Theories of Imperialism, Londra, Routledge, 2002; Sungur Savran, Kod Adı Küreselleşme: 21. Yüzyılda Emperyalizm, İstanbul, Yordam Kitap, 2008. 
açmasıyla sonuçlanan bu dönemde başta Rudolf Hilferding, Nikolay Buharin, Rosa Luxemburg ve Karl Kautsky olmak üzere çeşitli düşünür ve yazarlar Marksist teoriden yola çlkarak emperyalizmi anlamaya ve analiz etmeye çalışmışlardır. Öyle ki, bundan sonraki tartışmalar bu metinler referans alınarak yapılmıştır. Birinci Dünya Savaşı’nın ortaya çıkardığı politik bağlam içinde yalnızca bu yazarlar değil, John Hobson ve Joseph Schumpeter gibi liberal yazarlar da kapitalist ülkelerdeki sermaye birikimi ve bunun yarattığı uzak, deniz aşırı coğrafyalara yayılma olgusunu fark etmişlerdir. Marksist yazar ve düşünürler ise bunun bir paylaşım ve -Kautsky’i dışında tutarsak- emperyalist güçleri mutlak çatışmaya götürecek bir rekabet ve mücadele olduğu konusunda oydaşmakla birlikte, bunun nasıl ve hangi aşamada gerçekleşeceği konusunda farklı analizler geliştirmişlerdir.

Burada tüm bu yazarları ele almak mümkün değil, ama ana akım Uluslararası İlişkiler yazarlarının neredeyse yalnızca Lenin'in emperyalizm teorisini seçerek eleştirdikleri düşünüldügünde, Lenin'in perspektifine yoğunlaşmakta fayda olabilir. Emperyalizmi, kuramsal olarak ilk geliştiren olmasa da, Marksist literatürün içine yerleştiren Lenin olmuştur. Lenin, Hilferding ve bir ölçüde Hobson'dan da faydalanarak, içte monopollerin oluşması, finans kapitalin sanayi sermayesiyle birleşmesi, bunun uluslararası tekellerin oluşmasına neden olması ve dünyanın paylaşımı gibi aşamalardan söz ederek, emperyalizmi kapitalizmin en üst aşaması olarak tanımlar. Emperyalizmi belli bir aşamayla tanımlamak ve bunu bir zorunluluk olarak görmek tartışmalı olmakla birlikte, Lenin’in sözünü ettiği sermayenin aşırı yoğunlaşması ve azalan kâr oranlarının, burjuvaziyi yeni coğrafi alanlara açılmaya zorlaması ve bunun da kaçınılmaz olarak bir çatışmaya yol açacağını ileri sürmesi daha sonraki tartışmalar üzerinde çok etkili olmuştur. Ayrıca, Lenin emperyalizmin yalnızca dışarısıyla ilgili bir olgu olmadığını, emperyalizmin aynı zamanda içteki nüfus fazlasının ve işçi sınıfının sıkıntılarının toplumsal patlamalara yol açmasının önlenmesi için de yararlı bir mekanizma olduğunu dönemin siyasetçilerine atıfla belirtir. ${ }^{38} \mathrm{Bu}$ tartışmalar içinde, günümüzdeki yansımaları açısından da önemli olan Karl Kautsky'nin “ultra-emperyalizm” kuramı diğer yaklaşımlardan ayrılmaktadır. Kautsky, gerek içerideki işçi sınıfı karşısındaki konumunu zayıllatması, gerekse savaşın getirdiği maliyetin burjuvazinin elde edeceği kazançtan daha fazla olması gibi nedenlerle, emperyalistlerin çatışmak yerine işbirliği yapabileceğini söyler.

Dikkat edilmesi gereken husus tüm bu tartışmaların henüz Uluslararası İlişkiler bölümleri kurulmadan ve disiplin formel bir alan olarak tanımlanmadan önce gerçekleşmiş olmasıdır. Sonuçta, emperyalizm olgusuna yaşadıkları dönemde tanıklık etmiş olan Marksist yazarlar, bir yandan kapitalist devletlerin iç ekonomik yapılarını, öte yandan bunun küresel siyasete yansımalarını, çatışma ve savaşın altında yatan nedenleri ve bunun kolonilerde yarattığı etki ve dönüşümler ile bu sürecin tekrar içeride sınıfsal ilişkiler üzerindeki etkilerini incelemişlerdir.

Günümüzde emperyalizm kuramına sol gelenekten de bazı önemli eleştiriler gelmiştir. Örneğin, Samir Amin Lenin'in, emperyalizmi kapitalizmin en üst aşaması olarak görmesini eleştirerek, kapitalizmin her aşamada yayılma eğiliminde olduğunu belirtmiştir. ${ }^{39}$ Andrew Gamble Marksizm'in yaratıcılığının emperyalizm teorisi gibi Realist doktrinler tarafindan dondurulduğunu söylerken, ${ }^{40}$ Andrew Davenport Marksist uluslararası ilişkiler anlayışının son kertede Gerçekçilik teorisinin içine sıkışıp kaldığını, Marksizm’in siyasal olanı kuramsallaştıramamasının Gerçekçiliğe karşı pozisyonunu

38 V.I. Lenin, Emperyalizm: Kapitalizmin En Üst Aşaması, Ankara, Sol Yayınları, 1965, s. 111.

39 Samir Amin, "The Trajectory of Historical Capitalism and Marxism's Tricontinental Vocation," Monthly Review, Cilt 62, No.9, Şubat 2011.

40 Andrew Gamble, "Marxism After Communism: Beyond Realism and Historicism”, Review of International Studies, Cilt 25, No.5, Aralık 1999, s. 131. 
zayıflattığını söyler. Aslında Davenport, Marksizm’e Uluslararası İlişkiler bağlamında yöneltilen genel bir eleştiriyi, tek bir kapitalist üretim biçimi olduğu halde, çok sayıda siyasal birimin -ulusal devletlerolması çelişkisini sorunsallaştırır. Marksizm' in ve ondan türeyen yaklaşımların "siyasal” (the political) olanın neden ortaya çıktığını açıklayamadığını, sorunsallaştırmadığını ve üzerine yeterince teori geliştirmediğini, dolayısıyla "uluslararası" (the international) olanı da açıklayamayıp, Gerçekçiliği aşamadığını ileri sürer. Bu iddiaya göre, Marksizm bu durumu açıklamayı denediğinde ise yine siyasal parçalanmışlığın (yani devletler sisteminin) içinde kalır ve jeopolitiği zorunlu olarak kurama katar. ${ }^{41}$ Oysa sermaye birikimi hakkındaki kuramlar, sermaye birikiminin sürekliliği ve dolayısıyla kapitalist üretim ilişkilerinin ortaya çıkabilmesi ve sürdürülebilmesi için çok sayıda ulus-devletlere bölünmüş bir siyasal yapının zorunluluğundan bahseder. Dolayısıyla çelişki olarak ortaya konulan bu sorunsal, aslında devletlerarası sistemin varlık nedenini açıklayan kurucu bir özelliktir. Davenport'un Marksizm’e yönelttiği bu eleştirilerin merkezinde yer alan siyasal olanın açıklanmadığı iddiası, klasikleşmiş “Marx'ın bir devlet teorisi geliştirmediği” iddiasının devamı gibi görünmektedir; ${ }^{42}$ bu da Marksizm tartışmaları açısından özgün bir eleştiri değildir. ${ }^{43}$

\section{Sistem Karşıtı Tarihsel Maddeci Yaklaşımlar}

ABD, Soğuk Savaş koşullarında Marksizm’e alternatif olarak, Talcott Parsons'ın yapısalcı ve işlevselci bir Weber yorumunu temel alan Modernleşmeci yaklaşımı dış politikasında uygulamaya sokmuştu. ${ }^{44}$ Modernleşme Kuramı, W.W. Rostow'un kalkınmanın beş aşaması yaklaşımında belirttiği gibi, ${ }^{45}$ devletleri doğrusal bir gelişim çizgisi üzerinde belirli aşamalarda tanımlarken, azgelişmişliğin de çevre devletlerin kendi içlerindeki yapısal eksikliklerinden kaynaklandığını iddia ediyordu. İkinci Dünya Savaşı'nın ardından ABD’nin Üçüncü Dünya Ülkelerine yönelik perspektifini ve politikalarını şekillendiren Modernleşme Kuramı’na Latin Amerika temelli bir eleştiri gelişti: Bağımlılık Okulu.

Merkezin kolonilere yayılmasını ve bunun merkez içinde yarattığı sonuçları analiz eden emperyalizm kuramlarından farklı olarak Bağımlılık Okulu merkezin çevreden siyasal olarak çekilmesini, yani de-kolonizasyonun sonuçlarını inceliyordu. Klasik emperyalizm kuramları tek tek emperyalist ülkelere odaklanırken ve emperyalizmi ulus-devletlerin ve ulusal ekonomilerin bir faaliyeti olarak görürken, Bağımlılık Okulu hem sistemik (holistik) bir perspektif benimseyerek dünya ölçeğinde bir analiz yapıyor hem de disiplinerarası bir yöntem kullanıyordu. Bağımlılık Okulu merkezi kapitalist ülkeler arasındaki çatışmalara değil, merkezle çevre arasındaki bağımlılık ve sömürü ilişkisi ile gelişmişlik-azgelişmişlik sorunsalına odaklanıyordu. Klasik emperyalizm kuramlarında çevre, yani koloniler, emperyalist ülkeler arasındaki mücadelede birer nesne durumunda ele alınırken, Bağımlılık Okulu çevre ülkeleri özne konumunda ele alıyordu.

41 Andrew Davenport, “Marxism in IR: Condemned to a Realist Fate?”, European Journal of International Relations, Cilt 19, No. 1, Mart 2013, s.28, 42.

$42 \mathrm{Bu}$ eski tartışma için bkz. Bob Jessop, The Capitalist State, New York, New York University Press, 1982; Türkiye bağlamında benzer bir tartışma için bkz. İlhan Uzgel, Ulusal Çıkar ve Dış Politika, Ankara, İmge, 2004.

43 Devlet konusunda Marksist yazın içindeki geniş tartışmaların öncesinde, Marx, devleti, dış ticareti ve dünya piyasasını sermayenin örgütlenmesi bağlamında ele alır. "Ulus” kapitalist üretim ilişkilerinin içinde örgütlendiği esas birim olarak görülür. Bkz. Karl Marx, 1844 El Yazmaları (çev. Kenan Somer), Ankara, Sol Yayınları, 1993.

44 Chantal Thomas, "Max Weber, Talcott Parsons and the Sociology of Legal Reform: A Reassessment with Implications for Law and Development," Minnesota Journal of International Law, No. 15, 2006, s. 383.

45 Walt Whitman Rostow, The Stages of Economic Growth: A Non-Communist Manifesto, Cambridge, Cambridge University Press, 1990. 
Azgelişmişliği dünya ölçeğinde kapitalist sistemin tarihsel gelişimi ile merkez ve çevre arasındaki yapısal eşitsizlikler üzerinden tanımlayan Bağımlılık Okulu'nun bir kanadı BM Latin Amerika Ekonomik Komisyonu (ECLA) bünyesinde gelişirken, ${ }^{46}$ bir diğer kanadı ise Yeni-Marksist bir çizgiyi benimsedi. ECLA çevresi sistemdeki yapısal eşitsizliklere Marksizm'den farklı olarak kalkınmacı bir yaklaşım geliştirirken devrimci bir kopuş öngörmüyordu. Aksine, devlet eliyle ulusal sanayilerin geliştirilmesi ve ulus devletler içinde kapitalist üretim ilişkilerinin konsolidasyonunu bir kalkınma pratiği olarak tanımliyordu. ${ }^{47}$

ECLA'yı dar bir iktisat çerçevesine hapsolmakla eleştiren Yeni-Marksistler ise çevre ülkelerin ancak merkezden koparak kendi ekonomik gelişmelerini sağlayabileceklerini söylediler. Bu görüşün temsilcilerinden Andre Gunder Frank, Latin Amerika üzerine yaptığı çalışmada, bu bölgede, merkezdeki kriz (örneğin, Napolyon savaşları, 1929 krizi, İkinci Dünya Savaşı) ile ekonomik gelişme arasında bir bağlantı tespit ederken, çevre ülkelerin küresel kapitalizmle bağlarını gevşettikleri ölçüde ekonomik kalkınma sağlayabileceklerini ileri sürer. ${ }^{48}$ Yeni-Marksizm, Marx' ın kolonizasyon süreci hakkında ileri sürdügü tezin aksine, merkezin çevreyi dönüştüreceğini kabul etmekle birlikte, bu dönüşümün çevrede kontrollü bir ekonomik gelişmeye neden olduğunu ve gelişimi engellediğini savunur.

Tahmin edilebileceği gibi, Yeni-Marksist yaklaşım dünya siyasetine dair sosyal bilimler açısından önemli kavramlar geliştirip, yeni bir bakış açısı sağlamışsa da, hem ortodoks Marksistler, hem de ana akım tarafından eleştirildiler. Bu yaklaşımlara yönelik en önemli Marksist eleştiri, analizin merkezine üretim süreçlerinden çok eşitsiz değişim kavramını yerleştirmeleri, ${ }^{49}$ kapitalizme değil, azgelişmişliğe karşı tavır almaları $^{50}$ ve bazı durumlarda merkez ülkelerdeki işçi sınıflarını da dâhil ederek merkez ulusların çevre ulusları sömürdüğ̈nü ileri sürmeleriydi. Liberal eleştiri ise daha çok kapitalist sistemden ve merkezden kopmanın, ekonomik gelişme değil, daha fazla gerileme getireceği ve Uzak Doğu ülkeleri gibi, merkezle ekonomik bağları güçlendiren ülkelerin daha hızlı kalkındıkları gibi ampirik veriler üzerinden şekillendi. Yine metodolojik açıdan bu yaklaşımlar, amil/eden (agent) unsurunu dikkate almamaları ile devletleri edilgin aktörler ve yapıyı belirleyen olarak tanımlamalarından dolayı eleştirildiler. ${ }^{51}$

Yeni-Marksist yaklaşımla paralel tezleri olan ancak Marksist göndermelerden çok Fransa'da gelişen Annales okuluna da dayanan Dünya Sistemi Yaklaşımı ise en genel hatlarıyla, kapitalist bir dünya sisteminin 16. yüzyıldan itibaren Avrupa-merkezli olarak şekillenmeye başladığını söyler. Kapitalist bir dünya sisteminin temelini oluşturan Avrupa merkezli bu yapı, çevre ile ilişkileriyle birlikte şekillenmiştir. ${ }^{52}$ Görüldüğü gibi, Marksizm kapitalizmi üretim ilişkileriyle açılklarken, Dünya Sistemi Yaklaşımı küreselleşme eğilimindeki bir dünya pazarının oluşmasıyla, yani daha çok mübadele ilişkileriyle açıklar.

Uluslararası İlişkilerin temel analiz birimi devlet iken, Dünya Sistemi Yaklaşımının temel analiz birimi dünya sistemidir. Devletler hala bir analiz konusu olabilir, fakat analitik olarak dünya ekonomi-

46 Theotonio Dos Santos, “The Structure of Dependence”, American Economic Review, No. 60, 1970, s. 231-236.

47 Joseph L. Love, "The Origins of Dependency Analysis”, Journal of Latin American Studies, No. 22, 1990, s. 143-168; Ali Murat Özdemir, Uluslarm Sefaleti, Ankara, İmge Kitabevi, 2010; Fernando Henrique Cardoso and Enzo Faletto, Dependency and Development in Latin America, University of California Press, 1979.

48 Andre Gunder Frank, Capitalism and Underdevelopment in Latin America: Historical Studies of Chile and Brazil, Londra, Monthly Review Press, 1969.

49 Arghiri Emmanuel, Unequal Exchange, Londra, New Left Books, 1972.

50 Ernesto Laclau, "Feudalism and Capitalism in Latin America”, New Left Review, Sayı 67, Mayıs-Haziran 1971, s. 19-38.

51 Türkçe literatürde bu konudaki kapsamlı bir derleme için bkz. Haldun Gülalp, Yeni Marksizm Teorilerinin Eleştirileri, İstanbul, Birikim Yayınları, 1979.

52 Anibal Quijano and Immanuel Wallerstein, "Americanity As a Concept: Or the Americas in the Modern World-System”, ISSA, Say1 1, 1992, s. 549-557. 
sinden bağımsız olarak ele alınamayacağı için analiz birimi olamaz. Wallerstein'e göre, modern devletlerarası sistem, sonsuz bir sermaye birikiminin sağlanması için gerekli koşuldur. İmparatorluk düzeninin karşısına koyduğu parçalanmış egemenlikler üzerine kurulu bir devletlerarası sistem, imparatorluk yapısının ve mantığının engellediği sermaye birikiminin oluşmasının önünü açmıştır. ${ }^{53}$ Aynı yaklaşım içinde sayılabilecek olan Giovanni Arrighi’ ye göre ise, parçalanmış egemenliklerin arasındaki yarış zorunlu olarak sermaye birikimini kolaylaştırmaz. Esas önemli olan devletler arası mücadelenin şekli ve yoğunluğudur. Arrighi’nin yorumuyla kapitalist üretim ilişkileri tarihi hegemonyalar zinciri tarihidir. Tarihsel olarak Hollanda, Birleşik Krallık ve ABD hegemonyalarıyla birlikte her seferinde kapitalist üretim ilişkilerinin coğrafi kapsamı genişlemiş ve niteliği değişmiştir. ${ }^{54}$ Uluslararası ilişkilerin güncel durumuna ilişkin ise Wallerstein ve Arrighi, $\mathrm{ABD}$ hegemonyasının düşüşü konusundaki yorumları ön plana çıkarmışlardır. ${ }^{55}$

Aslında, dünya siyasetinde Batı tarafından da desteklenen kalkınmacı bir döneme denk gelen ama çevrenin ekonomik geri kalmışlığının sorumluluğunu merkezi kapitalist ülkelere yükleyen bu yaklaşımlar tek bir disiplinin alanına girmezler. İronik olan ise bu grubun içinde sosyologlar, iktisatçılar, siyaset bilimciler olmasına rağmen, Uluslararası İlişkiler çalışanların olmamasıdır. İngiltere ve ABD kökenli Marksist yazarlar kadar Samir Amin, Andre Gunder Frank, Giovanni Arrighi ve Johan Galtung gibi köken olarak Anglosakson olmayan yazarlar da bu tartışmalarda yer almış ve katkı sağlamışlardır. ABD merkezli Monthly Review dergisi etrafında toplanmış olan Paul Baran, Paul Sweezy, Harry Magdoff gibi Yeni-Marksistler ile Dünya Sistemi Yaklaşımını geliştiren Immanuel Wallerstein, aslında uluslararası sistemin yapısına, işleyiş dinamiklerine, kuruluş ve gelişim süreçlerine dair önemli tezler ileri sürerken, Uluslararası İlişkiler ana akımıyla herhangi bir temas ve diyalog içine girmemişler, kendi bağımsız metodoloji ve epistemolojileri olan alanlar kurmuşlardır. Bunda zaten söz konusu yazarların akademik köken olarak Uluslararası İlişkiler dışından gelmeleri kadar, muhtemelen o dönemde hala devlet merkezli ve güvenlik öncelikli paradigmanın hâkim olduğu akademik yazımla tartışmaya girmenin bir katkısı olmayacağını düşünmeleri rol oynamıştır. Söz konusu yazarlar, akademik bir tartışma yürütmeleri gerektiğinde bunu, Uluslararası İlişkiler disipliniyle değil daha çok iktisat ve sosyolojiyle yürütmüşler, eleştirilerini daha çok bu disiplinlerin ekonomik kalkınma, uluslararası ticaret, toplumsal değişim ve modernleşme kuramlarına yöneltmişlerdir.

Oysa Bağımlılık Okulu ve devamındaki Yeni-Marksistler ile Dünya Sistemi yaklaşımı sorunlarına rağmen, uluslararası ilişkilerin işleyişine dair alternatif bir bakış açısı getirmişlerdir. Küresel siyaseti Doğu-Batı, savaş-barış, çatışma-işbirliği; akademik alanı ise İdealizm-Realizm, Gelenekselci-Davranışsalcı gibi ikili karşıtlıklarla kuran ana akım Uluslararası İlişkilere, dünyada merkez ve çevre ülkeler ayrımının da olduğunu, bunlar arasındaki ilişkilerin eşitsiz kurulduğunu ve sistemin bu eşitsizliği yeniden ürettiğini, bunun sonuçlarının devletlerin bekaları kadar doğrudan insanların yaşam koşullarıyla da ilgili olduğunu göstermişlerdir. Bütün bu tartışmalar Marksizm’le bağlantılı olmakla birlikte, doğrudan onun uzantısı olmayan, hatta onunla çelişen yönler de içermektedir. Bu nedenle, 1980’lerden itibaren disiplinin ders kitaplarında artık bazen Marksizm bir alt başlık olarak yer alsa da, ondan türeyen yaklaşımlar globalist, Uluslararası Siyasal İktisat, radikal yaklaşımlar başlıkları altına ele alınmış ama ${ }^{56}$ her durumda bu yaklaşımlar disipline önemli bir etkide bulunmamıştır.

53 Immanuel Wallerstein, Geopolitics and Geoculture: Essays on the Changing World-System, Cambridge University Press, 1991.

54 Giovanni Arrighi, The Long Twentieth Century: Money, Power and the Origins of Our Times, Verso, 1994.

55 Immanuel Wallerstein, Amerikan Gücünün Gerileyişi, İstanbul, Metis, 2004; Giovanni Arrighi, "Hegemony Unravelling", 1 ve 2, New Left Review, Cilt 32, Mart-Nisan 2005 ve Cilt 33, Mayıs-Haziran 2005.

56 Örneğin Dougherty ve Pfaltzgraff, Contending Theories of International Relations, Pearson, 2009; Paul Viotti ve Mark Kauppi, International Relations, s. 449-530. 


\section{Uluslararası Iliş̧kiler İçinde Bir İstisna: "Marksist Uluslararası İlişkiler"}

İngiltere'de 1980'lerden itibaren yeniden canlanmaya başlayan Marksizm tartışmalarının doğrudan Uluslararası İlişkiler çalışmalarına da yansıması oldu ve ABD örneğinden farklı olarak, Marksizm İngiltere'de Uluslararası İlişkiler alanı içinde tartışma konusu haline geldi. Hepsi doğrudan kendisini Marksist olarak tanımlamasa da, buradaki Uluslararası İlişkiler akademisyenleri, disiplin ile Marksist teori arasında bağ kurmaya çalıştılar ve bu sorunlu ilişkiyi akademik düzlemde 2000'li yıllar boyunca canli tuttular.

Marksizm ve Uluslararası İlişkiler arasındaki ilişkiyi akademik açıdan inceleyen Marxism-Leninism and the Theory of International Relations başlıklı ilk kitabı Kubalkova ve Cruickshank, 1980 gibi Soğuk Savaş koşulları altında erken sayılabilecek bir tarihte çıkardılar. Bu kitap ve 1989'da yenilenen çalışmaları Marxism and International Relations İngiliz akademik camiası içinde sol gelenekten gelenler tarafından takdir toplamış olsa da, ciddi eleştirilerle karşılandı. ${ }^{57}$ Özellikle, Fred Halliday doğrudan bu iki yazarı, Marksizm ile Uluslararası İlişkiler arasında ikincisinden yana bir hiyerarşi kurmaları, Marksizm'in tek temsilcisi olarak Sovyetleri göstermeleri gibi gerekçelerle sert bir şekilde eleştirdi. ${ }^{58}$ Andrew Linklater, bu isimlerin Gerçekçilik ve Marksizm’i birleştirmeye çalıştıkları tespitinde bulunurken, ${ }^{59} \mathrm{John}$ Maclean daha ağır bir eleştiri getirerek Kubalkova ve Cruickshank' in Marksizm'in Uluslararası İlişkiler dışında tutulmasına katkı sağladıklarını belirtti. ${ }^{60}$ Aslında bu iki yazar Marksizm'i Uluslararası İlişkiler ile ilişkilendirmeye çalışırlarken, ilginç bir yol izleyerek, Marksizm’i, İngiliz Okulunda bahsi geçen üç gelenek -Realist (Hobbes), Rasyonalist (Grotius), Devrimci (Kant)- içine yerleştirdiler. Bu bağlamda, Marksizm’in sınıfsız dünya öngörüsünü yalnızca Gerçekçilik ile değil, Kantçı gelenekle birleştirmeye, hatta ona indirgemeye çalıştılar.

1990’larda İngiltere'deki Marksizm ve Uluslararası İlişkiler ilişkisinde yaşanan canlanma ABD'ye yansımadı. İngiltere'de özellikle Fred Halliday'in Rethinking International Relations ${ }^{61}$ kitabında tarihsel materyalizm ile Uluslararası İlişkilerin zorunlu olarak temas edeceğini savunması, Justin Rosenberg'in The Empire of Civil Society ${ }^{62}$ çalışmasıyla Gerçekçiliğe kapsamlı bir eleştiri getirip, uluslararası sistemin tarihsel temellerini Marksizm'den yararlanarak ortaya koyması ve Simon Bromley'in Rethinking Middle East Politics ${ }^{63}$ başlıklı çalışmaları, Marksizm'i ve yöntemsel olarak tarihsel materyalizmi Uluslararası İlişkiler disiplinine dâhil etme çabalarından öne çıkanlardı. Aynı şekilde 2007'den itibaren süren canlı tartışmalara, ${ }^{64}$ ABD'den farklı disiplinlerden Marksist analiz yapan yazarlar katılırken, ABD’li Uluslararası İlişkiler akademisyenleri herhangi bir şekilde dâhil olmadılar. Bunlar ortodoks Marksizm’i görmezden geldikleri gibi, İngiltere Uluslararası İlişkiler camiasında yürütülen tartışmalara da ilgi göstermediler.

57 V. Kubálková ve A. Cruickshank, Marxism-Leninism and the Theory of International Relations, Londra, Routledge, 1980; Marxism and International Relations, Oxford, Oxford University Press, 1989.

58 Fred Halliday, "Vigilantism in International Relations: Kubalkova, Cruickshank and Marxist Theory," Review of International Studies, Cilt 13, No.3, 1987, s. 164-165.

59 Andrew Linklater, "Realism, Marxism and Critical International Theory," Review of International Studies, Cilt 12, No. 4, Ekim 1986, s. 301-312.

60 John Maclean, “Marxism and International Relations”, s. 311.

61 Fred Halliday, Rethinking International Relations, Vancouver, UBC Press, 1995.

62 Justin Rosenberg, The Empire of Civil Society, Londra, Verso, 1994.

63 Simon Bromley, Rethinking Middle East, Austin, University of Texas Press, 1994.

$64 \mathrm{Bu}$ tartışmaların derlemesi için Bkz. Alexander Anievas (der.), Marxism and World Politics. 
Tartışmaların merkezinde, aslında Amerikan sol geleneğinin de uzun süredir gündeminde olan, uluslararası sistemin yapısı ile kapitalizm arasındaki ilişki yatmaktadır. Buradaki temel soru şudur: "Eğer kapitalizm bütüncül, birleşik bir birikim rejimi ise neden siyasal parçalanmaya, yani birden fazla devlete ihtiyaç vardır?” Alex Callinicos'un 2007'de yayınlanan “Does Capitalism Need the States System?” başlıklı makalesi, bu soruya yanıt ararken, Marksizm’e yakın duran İngiliz Uluslararası İlişkiler çevrelerinde geniş kapsamlı bir tartışma başlattı. Bu makalesinde Callinicos, David Harvey ile paralel şekilde ${ }^{65}$ ama ondan bağımsız olarak sermaye ve jeopolitik mantık arasında bir ayrıma gitmektedir. Callinicos burada devletler sisteminin kendisine özgü bir mantığı olduğundan ve Marksist Uluslararası İlişkiler analizinin Gerçekçi bir uğrak noktası olduğundan söz eder. ${ }^{66}$ Yani uluslararası sistemde kendi mantığı olan bir jeopolitik rekabet vardır ve devletler sistemi içindeki rakip siyasal elitlerin arasındaki etkileşim ve stratejiler analize dâhil edilmelidir. Fakat Justin Rosenberg ile birlikte, İngiltere'de sayıca az kalmış Troçkist geleneğe bağlı olan Callinicos'u daha orijinal kılan iddiası, tek bir kapitalist sistemde çok sayıda kapitalist devletin bulunmasını Troçki'nin "birlikte ve eşitsiz gelişim" tezine bağlamasıdır. Buna göre, kapitalizm bir zorunluluk olarak farklı coğrafyalarda farklı gelişmişlik düzeylerine ulaştı̆̆ için, bunların siyaseten ifadesi olarak bir devletler sistemi doğmakta ve kendisini yeniden üretmektedir. Kapitalizmde içsel olarak bulunan farklı gelişim dinamikleri, yenilikçilik, kâr arayışları, üretkenliğin artması gibi özellikler siyasal alana da taşmaktadır. Bu durum tek bir siyasal birimi, ulusaşırı devleti imkânsız kılmakta, küresel birikim süreci yeni-klasik iktisatçıların iddia ettikleri gibi, ekonomileri eşitlememekte, tersine dünya ekonomisinin belli bölgelerini daha ayrıcalıklı kılmaktadır. Eşitsiz gelişim kapitalizmin tesadüfi değil, içsel bir özelliğidir.

$\mathrm{Bu}$ yaklaşım, literatür içinden ciddi eleştirilere maruz kaldı. Öncelikle Lacher ve Teschke, kapitalizm ve devletler sistemi arasında zorunlu bir bağ bulunmadığını ileri sürdüler. Bu iki yazara göre, devletler sisteminin feodal dönemden arta kalan niteliği kapitalizm döneminde yeni bir üretim biçimi altında devam etmektedir. ${ }^{67}$ John Hobson, Callinicos'u kurtulmak istediği indirgemecilikten çıkamamakla ve 1980 'lerin iki mantık (sermaye ve jeopolitik mantık) tartışmasına geri dönmekle, ${ }^{68}$ Pozo-Martin, araçsalcılık ile Siyasal Marksizm arasında kalmakla ve Realizmi tanımlamadan ona başvurmakla eleştirdi. ${ }^{69}$

Callinicos'un perspektifi birçok açıdan sorunlu olsa da, Marksizm’e ait kavramların tartışıldığ metinlerde Uluslararası İlişkilere ait kavramların da yer alması, hatta buna tarihsel sosyoloji perspektifinin katılması ve derinlikli belli bir praxis'e dayalı (hegemonya, kapitalizmin dönüşümü ve mevcut niteliği ile bunların Marx, Lenin, Buharin ve Troçki’nin yazdıklarındaki karşılıkları) analizlerin yapılması, Uluslararası İlişkiler disiplini için sınırlı ama önemli kazanımlar olmuştur. Sonuçta başta Fred Halliday, Kubalkova ve Cruickshank, Alex Callinicos, Justin Rosenberg, John Maclean, Hazel Smith, Alexander Anievas, Andrew Davenport gibi yazarlar sınıf ilişkileri, kapitalizmin ortaya çıkış dinamikleri, devletin tarihsel kökenleri ve toplumsal sınıflar karşısındaki konumu, bunun diş politikaya ve küresel siyasete yansımaları gibi "uluslararası" (the international) olan ile ilgilenmeye ve bunları

65 David Harvey, Yeni Emperyalizm, İstanbul, Everest Yayınları, 2004.

66 Alex Callinicos, "Does Capitalism Need the States System?", Cambridge Review of International Affairs, Cilt 20, No. 4, Aralık 2007, s. 543, 545.

67 Benno Teschke ve Hannes Lacher, "The Changing 'Logics' of Capitalist Competition”, Cambridge Review of International Affairs, Cilt 20, No 4, Aralık 2007, s. 566.

68 John Hobson, “Back to the Future of 'One Logic or Two': Forward of the Past of 'Anarchy versus Hierarchy'?", Cambridge Review of International Affairs, Cilt 20, No. 4, Aralı 2007, s. 581.

69 Gonzalo Pozo-Martin, “Autonomous or Materialist Geopolitics?", Cambridge Review of International Affairs, Cilt 20, No 4, Aralık 2007, s. 551-563. 
tartışmaya başladılar. Bu Uluslararası İlişkiler açısından hem içerik olarak yeni, hem de tartışmaya katılan akademisyen sayısı açısından zengindir. Bu tartışmalar sırasında yazarlar Leninci ve Buharinci emperyalist, merkez-çevre ve kalkınma odaklı Yeni-Marksist teorilerden beslenmekle birlikte onları aşmaya, yeni küresel bağlamda bir yandan Uluslararası İlişkiler ile Marksizm arasında bir ilişki kurmaya, öte yandan da 2000'lerde iyice tıkanan ana akım Uluslararası İlişkiler disiplinine yeni bir açılım getirmeye çalıştılar.

\section{Uluslararası İlişkiler İçinde Dönüşüm: Eleştirel Kuram}

Uluslararası İlişkiler disiplininde Marksizm’i temsil etmese de, ondan esinlenerek yer alabilen ilk ve tek teori Eleştirel Kuram olmuştur. Eleştirel Kuram'ın beslendiği iki entelektüel kaynağın ilki temelde işçi sınıfının devrimci niteliğini kaybettiğini, ideoloji ve kültürün daha önemli olduğunu savunan, aydınlanma ve rasyonaliteyi eleştiren, pozitivizme tavır alan Frankfurt Okulu, ${ }^{70}$ diğeri ise aşağıda ele alınacak olan Gramsci'nin tezleridir. Burada Eleştirel Kuram'ın Andrew Linklater ve Mark Hoffman gibi yazarlar tarafından temsil edilen Habermascı versiyonu değil, konuyla ilgisi nedeniyle, Kanadalı Robert Cox tarafından temsil edilen ve Yeni-Gramşiyan olarak tanımlanan versiyonu ele alınacaktır.

Cox öncelikle epistemolojik bir yenilik getirerek, hem Max Horkheimer hem de Michel Foucault gibi düşünürlere dayanmış ve iktidar ile bilgi/teori oluşumu arasındaki ilişkiyi vurgulamıştır. Bunun Uluslararası İlişkiler için anlamı, disiplindeki teorik bilgi oluşumuyla ABD hegemonyası arasındaki ilişkinin ortaya konmasıdır. Burada Cox, teoriyi sorun çözücü kuramlar ve eleştirel kuram olarak ele almış, her bir bilgi üretim sürecinin belli sınıfsal çıkarlara tekabül ettiğini belirtmiştir. 1960’ların içeriksiz ve yönteme odaklanan ikinci tartışmasının ardından, Cox aracılığıyla ilk kez disiplinin bütüncül olarak kuruluş dinamikleri, kavram ve kuram oluşturma süreçleri tartışmaya açılmış, bu teorilerin küresel hegemonik yapılanma ile bağı kurulmuştur. Bu arada, Cox'un yalnızca Yeni-Gerçekçilik akımının tarihsiz ve yapısalcı yöntemini ve politikayı maddi yeteneklere indirgeyen perspektifini değil, aynı zamanda Wallerstein ve Althusser gibi yazarların yapısalcılığını ve Marksizm’in ekonomik indirgemeciliğini de eleştirdiğini belirtmek gerekir. ${ }^{71}$

Bunun yanında Eleştirel Kuram, Uluslararası İlişkilere etik bir boyut katma iddiasını da taşır. ${ }^{72}$ $\mathrm{Bu}$, objektif gerçeklik iddiası üzerine kurulu Uluslararası İlişkiler disiplini için 1980'ler bağlamında çok önemli bir yenilikti. Yine Cox, ana akım kuramları objektif ve bilimsel, Marksizm’i ise yalnızca bir ideoloji olarak tanımlayan hâkim anlayışa karşı, Yeni-Gerçekçilik akımının "büyük gücün uluslararası sistemi yönetmesinin hizmetine girmiş bir bilim dalı olduğunu” ve aslında ideolojik olanın Yeni-Gerçekçilik olduğunu açıkça belirten ilk Uluslararası İlişkiler yazarı oldu. ${ }^{73}$

Cox hem Uluslararası İlişkiler söylemini kullanarak disiplinin kavram ve kuramlarıyla diyaloğa girmiş, hem de üretim ve toplumsal güçler, diyalektik, tarihsel materyalizm, hegemonya, güç ve rıza,

70 David Held, An Introduction to Critical Theory, Londra, Polity Press, 1990.

71 Robert Cox, "Social Forces, States and World Orders: Beyond International Relations Theory", Millennium, Cilt 10, No. 2, 1981, s. 126-155.

72 Stephen Gill, “Epistemology, Ontology and the Italian School”, Stephen Gill (der.), Gramsci, Historical Materialism and International Relations, Cambridge, Cambridge University Press, 1993, s. 24-25.

73 Robert Cox, "Postcript 1985", Robert Keohane (der.), Neorealism and its Critics, New York, Columbia University Press, 1986, s. 246; Robert Cox, "The Way Ahead: Toward a New Ontology of World Order", Richard Wyn Jones (der.), Critical Theory and World Politics, Boulder, Lynne Rienner Pub., 2001, s. 46. 
tarihsel blok gibi kavramları kullanarak disiplin içinde Marksizm’den gelen bazı kavramlara ve yönteme yer açmak istemişti. Aynı zamanda, bir yandan tarihsel materyalizmin Yeni-Gerçekçiliği ve aslında Uluslararası İlişkiler kuramlarını düzeltme potansiyelini göstermeye çalışmış, öte yandan devlet ve mevcut dünya düzeninin veri olarak alınmasını eleştirerek bunları sorunsallaştırmıştır. Uluslararası ilişkileri analiz ederken sınıf, sömürü, emperyalizm kavramlarını kullanmasa ve işçi sınıfına devrimci bir rol biçmese de; toplumsal güçler, devlet formları ve dünya düzenleri arasındaki diyalektik etkileşime dikkat çekmiş ve analizinin merkezine üretim ilişkilerini koyarken, bunu kurumlar, maddi yetenekler ve fikirler arasındaki ilişkiler etrafında tartışmıştır.

Genelde Eleştirel Kuram’ın dünya düzeninin verili olmadığını, aksine tarihsel ve diyalektik olduğunu savunması, dönüşümün hem mümkün olduğu, hem de mevcut düzenin bu dönüşümün tohumlarını içinde barındırdığı anlamına gelir. Dolayısıyla, Cox'un kuramı hem dönüşüme açı ve dolayısıyla özgürleştirmeci (emancipatory) bir perspektif taşırken, hem de karşı hegemonya üzerinden gerçekleştirilebilecek bu dönüşümün ipuçlarını verir.

Cox’un, Gramsci'den yola çıkarak geliştirdiği hegemonya kavramı, hem ontolojik hem de epistemolojik açıdan disipline yeni ve eleştirel bir perspektif sundu. Ontolojik açıdan hegemonyanın ulusal ölçekte başlayıp küresel bir boyuta taşındığını, ${ }^{74}$ yalnızca maddi güç ile değil, rıza, fikirler ve kurumlarla oluşturulduğunu ve devlete ait değil, hâkim sınıflarla ilgili bir olgu olduğunu söyleyerek, hem hegemonik düzenin analizini yaptı, hem de "devletin uluslararasılaşması" 75 kavramıyla kendisinden sonra gelen tartışmaların önünü açtı. ${ }^{76}$ Yeni-Gerçekçiliğin güç, Yeni-Liberalizmin ticaret, İngiliz Okulu'nun norm, Toplumsal İnşacılığın kimlik, Postyapısalcılığın söylem, Postmodernizmin yapısöküm üzerinden tanımladığı uluslararası ilişkilere, Eleştirel Kuram bu ilişkilerin sınıfsal niteliği olduğu, hegemonik olarak rızayla düzenlendiği ve tarihsel bir nitelik taşıdığını söyleyerek yeni ve dönüştürücü bir bakış açısı katmaya çalıştı.

Kuşkusuz, Cox'cu Eleştirel Kuram çok farklı geleneklerden ve perspektiflerden yoğun bir eleştiriye tabi tutuldu. Liberaller tarafindan radikal Marksist olmakla, Marksistler tarafindan ise Marksist olmamakla eleştirildi. Ayrıca, ampirisist ve indirgemeci olduğu da ileri sürüldü. ${ }^{77}$ Peter Burnham, Eleştirel Kuram'ı Weberci çoğulculuk içinde kalmakla eleştirirken, ${ }^{78}$ Pınar Bedirhanoğlu Cox'u, devleti otonom olarak kavramak ve Marksist üretim biçimini indirgemeci bir tarzda ele almakla, ${ }^{79}$ Fuat Keyman cinsiyet, kimlik gibi ötekileştirilmiş ve dışlanmış unsurları dâhil etmemekle, ${ }^{80}$ Jonathan Joseph üretim ilişkileriyle dünya düzenleri arasındaki bağı kurmamak ve özneler arası ilişkilerle maddi üretim

74 Robert Cox, "Gramsci, Hegemony, and International Relations: An Essay in Method", Robert Cox ve Timoth Sinclair, Approaches to World Order, Cambridge, Cambridge University Press, 1996, s. 137.

75 Robert Cox, "Global Perestroika”, Robert Cox ve Timothy Sinclair, Approaches to World Order, Cambridge, Cambridge University Press, 1996, s. 301.

76 Aşağıda da değinileceği gibi, bu tartışmanın önde gelen isimleri Stephen Gill, David Law, Mark Rupert, Adam Morton, Andreas Bieler, William Robinson ile 'Hollanda Okulu'nu oluşturdukları söylenen Kees van der Pijl, Henk Overbeek, Bastiaan von Apeldoorn gibi yazarlardır.

77 Cox'a eleştiriler ve onlara cevabı 2002'de şu kitapta toplandı: Robert Cox ve Michael Schechter, The Political Economy of a Plural World, Londra, Routledge, 2002.

78 Peter Burnham, "Neo-Gramscian Hegemony and the International Order", Andreas Bieler vd., (der.), Global Restructuring, State, Capital and Labour, Contesting Neo-Gramscian Perspectives, New York, Palgrave, 2006, s. 32.

79 Pınar Bedirhanoğlu, "The State in Neoliberal Globalization: The Merits and Limits of Coxian Conceptions”, Allison Ayers (der.), Gramsci, Political Economy and International Relations Theory, New York, Palgrave Macmillan, 2008 , s. 91.

80 Fuat Keyman, Küreselleşme, Devlet, Kimlik/Farklılık, İstanbul, Alfa, 2000, s. 167-168. Keyman’ın kitabının İngilizce orjinalinde yer alan ve Cox’a yönelttiği özellikle Avrupa merkezli ve eril olma eleştirilerden bir kısmı Cox'un eleştirileri yanıtladığı kitapta da yer almaktadır. Robert Cox ve Michael Schechter, Political Economy of a Plural World, s. 13. 
ilişkileri gibi ikili toplumsal ontolojiye dayanmakla ${ }^{81}$ eleştirdiler. Bu yazarların yaptığ kısaca, pozitivizm eleştirisi üzerine kurulan Yeni-Gramşiyan teorinin evrenselcilik iddiası üzerinden modernizme geri döndügünü ima etmektir. Bu argümanın anlamı, Eleştirel Kuram’ın materyalizme ve üretim süreçlerine yaptığı vurguyu terk ederek ya da geriye çekerek, göreceliğe ve öznelliğe ağırlık vermesidir.

Eleştirel Kuram’ı disiplin için değerli, önemli ve yaratıcı kılan, kimlik ve kültürel unsurlara değil, disiplinde yer bulamamış olan üretim ilişkilerine ağırlık vermesi, toplumsallığın üretim ilişkilerinin bir sonucu olduğunu söylemesiydi. Yoksa zaten 2000’lerde kimlik, öteki, farklılık, cinsiyet, etnisite gibi konular gerek Toplumsal İnşacılık, gerekse Postmodernizm ve Postkolonyalizm gibi perspektifler tarafından yoğun bir şekilde incelenecekti. Sonuçta, Yeni-Gramşiyan yaklaşım, Cox’un açtığı yoldan ilerlerken, Eleştirel Kuram, Uluslararası İlişkiler disiplininin içine kabul ettiği tek Marksist kökenli yaklaşım olarak tıpkı diğerleri gibi, bir yükseliş ve düşüş trendi yaşadı ve diğer kuram ve yaklaşımlardan biri haline dönüştü.

\section{Küreselleşme Ekseninde Uluslararası İlişkiler ve Marksizm}

Cox'un takipçileri özellikle hegemonya sorunsalı üzerinde dururlarken, 11 Eylül şoku ertesinde ABD'in açık bir kuvvet kullanma ve işgal politikasına yönelmesiyle, emperyalizm kavramını yeni koşullar altında tanımlamaya çalışan daha canlı bir tartışma süreci başladı. 2000'lerde yeni-liberal küreselleşme döneminde analizlerini Marksizm’e dayandıran yazarların bir kanadı İngiltere'deki Uluslararası İlişkiler camiasından, diğer kanadı ise ABD’den ama Uluslararası İlişkiler alanından değil, sosyoloji ve siyasal teori çalışanlardan çıktı. Küreselleşme dönemine kadar Marksizm için uluslararası ilişkiler doğrudan emperyalizmi ifade ederken, 1990’lardan itibaren küreselleşme olgusunu açılamaya, onu Marksist kavramlarla tanımlamaya yöneldi. Buradaki tartışmalar, Uluslararası İlişkiler teorileriyle kurulan bir diyalog şeklinde değil, daha çok Marksist yazarların kendi aralarında yürüttükleri bir 'emperyalizm' ve/veya 'küreselleşme' tartışması olarak gerçekleşti.

Bu noktada, küreselleşme bağlamı içinde yürütülen tartışmalar, kökenini yine sınıfsal yapılardan ve üretim ilişkilerinin küreselleşme çağındaki biçiminden alan iki farklı yaklaşımla değerlendirildi. Bunlardan ilki kuramsal bir tartışma olan, yeni-liberalizmle birlikte ekonomilerin ulusal niteliğinde yaşanan dönüşümün içeriği, boyutları ve özellikle merkezi kapitalist ülkeler açısından bunun sonuçlarıdır. Küreselleşmeci olarak adlandırılabilecek bazı yazarlar 1980’lerden itibaren hem merkez, hem de giderek çevrede ekonomilerin ulusal niteliklerinin ortadan kalktığını ve sermayenin üretim ve finans faaliyetinin ulusal devlet içinde değil, küresel olarak gerçekleştiğini, dolayısıyla birikim rejiminin küresel hale geldiğini ileri sürdüler. Genelde "Ulusaşırı Kapitalist Sınıf” (Transnational Capitalist Class) tezi olarak da anılan bu tezin kökenleri Cox'un devletin "uluslararasılaşması" kavramında yatmaktadır. Hatta bu yaklaşımlara genel olarak "ulusaşırı tarihsel materyalizm” de denmektedir. Kısaca söylemek gerekirse bu görüş emperyalizmin artık geçerliliğini yitirdiğini savunur.

İkinci görüş ise, küreselleşme çağında ekonomilerin ulusal niteliğinin ortadan kalktığı ve dolayısıyla emperyalizmin ve jeopolitiğin anlamını yitirdiği yolundaki teze itiraz ederek, Leninci çizgiyi takip eder ve emperyalist mücadelenin devam ettiğini savunur.

Bu tartışmaların bazı ortak noktaları da vardır: Öncelikle, tüm bu yaklaşımlar kapitalizmin küresel bir boyut kazandığını kabul eder ve bunun içinde finansal genişlemeye, Hilferding'in Marx’tan

81 Jonathan Joseph, "On the Limits of Neo-Gramscian International Relations: A Scientific Realist Account of Hegemony," Allison Ayers (der.), Gramsci, Political Economy and International Relations Theory, s. 68. 
aldığı, kapitalizmin gelişim sürecinde finansın sanayi sermayesinden kopup güçlendiği tezine dayanırlar. ${ }^{82}$ İkinci ortak nokta olarak, yine her iki yaklaşım da küresel ekonomi politiğin analizinde ABD'ye merkezi bir yer ayırırlar. Emperyalizm dendiğinde de aslında kastedilen ABD emperyalizmidir, yoksa tek tek Alman, Japon, Fransız vs. emperyalizmi değildir.

Aynı kategori altında ele almak zor olsa da, kapitalizmin ulusaşırı niteliği üzerinden analiz yapanların bir "post-hegemonik" dünya ekonomi politiğinden hareket eden Stephen Gill, William Robinson, Kees van de Pijl gibi yazarlar olduğu söylenebilir. Genel hatlarıyla, bu yazarlar emperyalizm kavramının günümüz küresel siyasetini açıklamakta yetersiz kaldığı noktasından hareket edip, bunun da altında yatan temel nedenin, kapitalizmin küresel (ulusaşırı) bir nitelik kazanması olduğunu, ${ }^{83}$ sermaye birikim sürecinin ulus devlet içine sığmamaya başladığını, dolayısıyla sermayenin belli bir toprak parçasıyla bağlı olmaktan çıktığını (de-territorialized), ulusaşırı kapitalist sınıfın devletler aracılığıyla yeni-liberal küreselleşmeyi yerleştirdiğini ileri sürmektedirler ${ }^{84}$ Van der Pijl, söz konusu ulusaşırı kapitalist sınıfın "Atlantik çekirdeği” dediği İngiltere ve ABD merkezli, liberal ilkelere dayalı Lockçu devlet-toplum yapısından türediğini, buradan da küresel ölçekte yayıldığını, bu projeye direnişin ise Hobbesçu devletler olan Fransa, Almanya ve Sovyetler Birliği’nden geldiğini ileri sürer. ${ }^{85}$

Bu perspektif içinde ele almak kolay olmasa da, çok ses getiren çalışmaları Imparatorluk'ta Hardt ve Negri de, küreselleşme süreciyle birlikte kapitalist birikim mantığının dönüşmesiyle devlet ile sermaye arasındaki bağın koptuğunu, her şeyi içine alan ve içselleştiren, merkezi olmayan yeni bir iktidar ve egemenlik biçiminin kurulduğunu ileri sürmektedir. Yazarlara göre, içerisi ve dışarısı kalmadığı için artık emperyalizmden söz edilemeyeceği gibi, hegemonyadan da söz edilemez; çünkü imparatorluk çağında tek bir ülke böyle bir işlevi istese de yerine getiremez. ${ }^{86}$

$\mathrm{Bu}$ yaklaşımların yalnızca Leninci emperyalizm teorisini yetersiz bulmakla kalmadıkları, emperyalist ülkelerin savaşmak yerine işbirliği yaparak "ultra-emperyalizm”e gideceklerini savunan Kautsky'nin teorisine de yakın durmadıklarını belirtmek gerekir. Çünkü Kautsky de sonuçta, ulusal ölçekte örgütlenmiş kapitalist devletlerin işbirliğinden bahseder; oysa ulusaşırı kapitalist sınıf tartışmaları, bunu aşarak sermayenin iç içe geçmişliğinden ve egemenlik formel olarak devam etse de Westphalian içeriğin boşaldığı görüşünden hareket etmektedirler.

$\mathrm{Bu}$ genel yaklaşımın karşısında ekonomilerin ulusal niteliğinin devam ettiği ve dolayısıyla emperyalist rekabetin de yeni biçimler altında sürdügünü savunan tezler bulunur. Başta Monthly Review çevresi olmak üzere John Bellamy Foster, James Petras, Peter Gowan ve David Harvey'in temsil ettiği bu yazarlara Samir Amin ve Alex Callinicos da dahil edilebilir. ${ }^{87}$ Ortak bir çıkış noktası olarak bu yazarların hepsi neoliberal küreselleşme çağında finans kapitalin daha akışkan hale geldiğini kabul etmekle birlikte, kapitalizmin ulusal niteliğinin kalmadığı yolundaki görüşe itiraz ederler. Bu görüşlere göre her finans ve sanayi grubu sonuçta bir devlete bağlıdır.

82 Rudolf Hilferding, Finans Kapital (çev. Yılmaz Öner), İstanbul, Belge Yayınları, 1995.

83 Stephen Gill, "Globalisation, Market Civilisation and Disciplinary Neoliberalism”, Millennium, Cilt 24, No. 3, 1995, s. 399-423; Gill, “The Global Panopticon? The Neoliberal State, Economic Life and Democratic Surveillance”, Alternatives, Cilt 20, No.1, 1995, s. 1-49.

84 William Robinson, "Capitalist Globalization and Transnationalization of the State", Mark Rupert ve Hazel Smith (der.), Historical Materialism and Globalization, Routledge, 2002, s. 212

85 Kees van der Pijl, The Making of an Atlantic Ruling Class, Londra, Verso, 1984, s. 2.

86 Michael Hardt ve Anthony Negri, İmparatorluk (çev. Abdullah Yılmaz), İstanbul, Ayrıntı, 2003.

87 Pijl küresel ölçekte bir rekabet sürecinin başladığından söz eder. Kees van der Pjil, Global Rivalries, from the Cold War to Iraq, Londra, Pluto Press, 2006. Türkiye’de bu görüşün temsili için bkz. Savran, Kod Adı Küreselleşme. 
Yeni emperyalizm kuramcıları Soğuk Savaş’ın bitişinden itibaren, merkezi kapitalist ülkeler arasında 19. yüzyıl sonunu andıran jeopolitik bir mücadelenin yeniden ortaya çıtığını ileri sürerler. Bu yaklaşımlarda, yine küreselleşme tartışmalarının aksine, devletin bir aktör olarak yeri ve önemini korumaya devam ettiği vurgulanır. Örneğin, Harvey gücün sermaye ve topraksal mantığını birbirinden ayırarak; ilkinin özel, ikincisinin kamusal çıkarları temsil ettiğini, emperyalist yayılmaya sermayenin aşırı birikim sorununa bir çözüm getirmek için başvurulduğunu ve ABD'nin Irak işgalinin bu bağlamda ele alınabileceğini savunur. Bunlar neredeyse 100 yıllık geçmişi olan emperyalizm tartışmasında çok yeni unsurlar değilse de, Harvey günümüzde Çin'in Batı'daki sermaye fazlasını çektiğini, onun bir aktör olarak güçlenmesini ise ABD’nin petrol musluğunu elinde tutarak denetim altına almaya çalıştığını söyler. ${ }^{88}$ Samir Amin de, sermayenin hiyerarşik bir nitelik taşıdığını, Hilferding' in belirtmiş olduğu gibi, finansal sermayenin oligopol oluşturarak ekonominin tepesini kontrol etmeye başladığını ama bu finans kesimlerinin belli devletlere bağlı olduğunu savunarak, Leninci anlamda bir çatışma olasılı̆̆ından söz eder. ${ }^{89}$

Marksizmin kendisine ilişkin bir kuramsal tartışmayı yaşadığımız dönemin somut pratiğiyle birleştirmekten çok, cari küresel gelişmeleri $\mathrm{ABD}$ hegemonyası/emperyalizmi eksenli ele alan bu tartışmaların doğrudan Marksizm' in kuramsal gelişimine katkısı sınırlı kalmıştır. Uluslararası İlişkiler açısından baktığımızda ise, yeni bir yöntem ve epistemoloji arayışından çok, ABD’nin Afganistan ve Irak işgallerinin yarattığı konjonktürel bir ilginin yansımasından söz edilebilir. 2000’lerde artık bir şekilde emperyalizm ve hegemonya tartışmaları, kaçınılmaz biçimde literatür ve ders planlarında yer almaya başladıysa da, sonuçta, yerleşik, kendi kavram seti, metodolojisi ve Lenin ya da Cox'un tezlerinden türetilmiş yeniden uyarlamalar dışında, kökenini Marksizm'den alan paradigmatik bir değişim disiplinde gerçekleşmemiştir.

Genel olarak bakıldığında, Uluslararası İlişkiler disiplininden daha eski olan Marksizm uluslararası olana baktığında Lenin'den bu yana ağırlıklı olarak emperyalizmi görmüş ve küresel siyaseti anlamaya ve analiz etmeye çalışmıştır. Bu süreçte, özellikle ortodoks Marksistler bir disiplin olarak Uluslararası İlişkilere, bu disiplinin Marksizm’e bakışından daha mesafeli durmuşlardır. Bunun nedenlerinden en önemlisi, geçmişte hem Sovyet modelinde hakim olan genelde Batı sosyal bilimini bir "burjuva” bilimi olarak görme eğiliminin Batılı Marksistlerde de bulunması kadar, Uluslararası İlişkiler disiplininin ağırlıklı olarak devlet ve güvenlik, jeopolitik ve ulusal çıkar temelli, bazen ampirik ve niceliksel kurgusunun, Marksist yazarlar açısından tartışma zemini olarak kabul edilmemiş olmasıdır. Örneğin, gerek ABD kökenli Marksistlerin dergisi Monthly Review gerekse İngiltere merkezli Socialist Register ve New Left Review gibi dergiler, ana akım Uluslararası İlişkiler teorileriyle herhangi bir diyaloğa girmemişlerdir. Bu noktada birleştirici rolü, disiplin için bir anomali sayılabilecek şekilde, İngiliz Marksist Uluslararası İlişkiler akademisyenleri oynamışlardır.

Marksizm, kendisine Uluslararası İlişkiler teorileri içinde bir yer aramak yerine, bu "burjuva bilim dalını" tasfiye edip, yerine geçmeyi talep eder. Uluslararası İlişkiler konusunda açıça dile getirilmeyen bu örtük iddia, ana akım Uluslararası İlişkiler disiplinini Marksist yaklaşımlardan uzak tutarken, Marksist yaklaşımların da, eleştirmek için bile olsa ana akımın teorilerine gönderme yapmaktan kaçınmalarına neden olmuş görünmektedir.

88 David Harvey, Yeni Emperyalizm.

89 Samir Amin, "Market Economy or Oligopoly-Finance Capitalism”, Monthly Review, Cilt 59, No. 11, Nisan 2008, s. 51-52, 58 . 


\section{Sonuç: Marksist Bir Uluslararası İlişkilere Giden Yol}

Marksizm (ve onun tarih içinde dönüşen yorumları) ile bir sosyal bilim alt disiplini olan Uluslararası İlişkilerin son yüzyıllık dönemde birbirleriyle ilişkisi, iki farklı metodolojik ekol ve iki farklı sosyal bilim anlayışının karşılıklı olarak tartışarak yürüttükleri bir rekabet değil, kendi korunaklı alanlarını bir diğerine karşı elden geldiğince kapatmaya çalışan ideolojik kamplar şeklinde gerçekleşmiştir. Aslında, ABD merkezli Batı küresel hegemonyasının ideolojik dayanaklarından biri olan sosyal bilimler içinde, bunun en doğrudan uzantısı olarak kurulup gelişen Uluslararası İlişkiler disiplini, bir yandan çoğulcu bir siyasal ontolojiye ve bunun metodolojik alanda sürdürdüğü iddiasına sahipken, diğer yandan söz konusu çoğulculuğun sınırlarını kendisi belirleyip, alternatif olanları merkezi kavram ve tartışmaların dişında tutmayı başardı. Bu nedenle Marksizm bütün sosyal bilim dalları arasında en az Uluslararası İlişkileri etkileyebildi.

Disiplinin kuruluşundan itibaren sürdürülen ikili karşıtlıklar, alternatifinin yine aynı "epistemik topluluk" tarafından belirlenmesine imkân sağlarken, zaten bu tartışmaların bir tarafında Gerçekçilik hep bir şekilde bulunuyordu. Dolayısıyla, disiplin içindeki tartışmalar, ontolojik karşıtıyla yürütülmediği için diyalektik olmaktan çok, sentetik bir nitelik taşıdı ve yeni bir senteze ulaşıp, disiplinin gelişimine katkı sağlayamadı. Buna bir de Gerçekçiliğin önce Yeni-Gerçekçilik, ardından Yeni-Klasik Gerçekçilik ve Savunmacı Gerçekçilik, 2000’lerde ise iyice kafa karışıklığı yaratan "Liberal Gerçekçilik”, ${ }^{90}$ ya da "Demokratik Gerçekçilik" gibi yeni tanımlamalarla ayakta kalma çabasını da eklemek gerekir.

Disiplinde 1980 sonrası çeşitlenen tartışmalar ve kavramlar, eleştirel dönüş ve dilsel dönüşüm ile birlikte devlet merkezlilik, pozitivizm ve modernizmin kuşatıcı, tahakküme alan açan yönlerini aşma potansiyeli taşıdıkları ölçüde kendi içlerinde anlamlı ve önemlidir. Fakat küresel siyasetin eşitsiz ve adil olmayan boyutlarını gölgelediği ölçüde de küresel ölçekteki eşitsizlik, dışlama ve devam eden sömürü ilişkilerinin yeniden üretilmesine katkıda bulunan kavramsal araçlar olma özelliği de taşırlar.

Oysa küreselleşme süreciyle birlikte finansal sermayenin akışkanlığının artması, uluslararası ticaret hacminde ve doğrudan yatırımlarda kaydedilen artış, merkezi kapitalist ülkelerde ortaya çıkan ekonomik kriz, bölgesel ekonomik örgütlenmelerin belirmesi, Çin ve Hindistan gibi büyük nüfus ve coğrafi alanların küresel kapitalist ilişkilere dâhil olmaya ve yeni işçi sınıfı ve orta sınıfların ortaya çıkmaya başlaması, tüketim alışkanlıklarının tarihin hiçbir döneminde olmadığı kadar yaygınlaşması gibi gelişmeler maddi ilişkilere dayanan dönüşümlerdi. Liberal küreselleşme söyleminde de yaygın olarak yer bulan "küresel köy” kavramında dile geldiği gibi, tüm bu süreçlerin analizinde, kapitalizmi bir devrimci ideoloji olarak olmasa da, altyapı ve üstyapı diyalektiğiyle incelemesinden sağlanacak yöntemsel katkılar mümkün olabilirdi; ama olmadı.

Aslında 1990'ların sonunda Uluslararası İlişkiler disiplinin kendisinde de bazı sorunlar yaşanmaya başladığına dair samimi tespitler yapılıyordu. Örneğin, Micheal Brecher 1999'da ISA toplantısında yaptığı açılış konuşmasında Uluslararası İlişkiler disiplinin bir tıkanma içine girdiği söylerken, ${ }^{91}$ aynı dönemde bu kez İngiltere’den Barry Buzan ile Richard Little, Uluslararası İlişkilerin diğer sosyal bilim dallarından beslenen ama onlara katkı sağlamayan bir disiplin olduğunu yazmışlardı. ${ }^{92}$

90 John Ikenberry, "Liberal Realism: The Foundations of a Democratic Foreign Policy", The National Interest, Sonbahar 2004, s. 38-51; Joseph Nye, “Toward a Liberal Realist Foreign Policy”, Harvard Magazine, Mart-Nisan 2008, s. 36-40.

91 Michael Brecher, "International Studies in the Twentieth Century and Beyond: Flawed Dichotomies, Synthesis, Cumulation”, International Studies Quarterly, No. 43, 1999, s. 214.

92 Barry Buzan ve Richard Little, "Why International Relations has Failed as an Intellectual Project and What to do About it?”, Millenium, Cilt 30, No. 1, 2001, s. 19-39. 
Marksizm bütüncül bir analiz yöntemi geliştirirken, bu Uluslararası İlişkiler alanına küresel siyasetin analizi olarak yansımaktadır. Oysa Marksizm’in bütünselliği yalnızca coğrafi mekâna değil, siyaset ve ekonomin kendisine yöneliktir. Kapitalizm bütüncül ve küresel bir olgu olabilir fakat her bir kapitalist coğrafyanın kendi dinamikleriyle ele alınması Marksist metodoloji açıdan gerekliliktir. Literatürün küresel siyasete odaklandığı bu durumda, Uluslararası İlişkiler bağlamında belirtecek olursak, Marksizm'in bir “mikro teorisi” olmadığı ve bu boşluğun özellikle Dış Politika Analizi ve Karar Verme Yaklaşımları tarafından doldurulduğu görülmektedir. Uluslararası İlişkilere Marksist bir bakışın olanaklılı̆̆ının önü, sadece disiplininin sınırlılıklarının aşılmasıyla değil, aynı zamanda Marksist kuramın uluslararası ilişkilere yönelik bir kavramsal alet kutusu geliştirmesiyle de açılacaktır. 


\section{Kaynakça}

Amin, Samir, “Market Economy or Oligopoly-Finance Capitalism”, Monthly Review, Cilt 59, No. 11, Nisan 2008.

Amin, Samir, “The Trajectory of Historical Capitalism and Marxism's Tricontinental Vocation," Monthly Review, Cilt 62, No 9, Şubat 2011.

Anievas, Alexander (der.), Marxism and World Politics: Contesting Global Capitalism, Routledge, 2012.

Aron, Raymond, Peace and War: A Theory of International Relations, New York, Doubleday \& Company, 1966.

Arrighi, Giovanni, “Hegemony Unravelling”, 1 ve 2, New Left Review, Cilt 32, Mart-Nisan 2005 ve Cilt 33, May1s-Haziran 2005.

Arrighi, Giovanni, The Long Twentieth Century: Money, Power and the Origins of Our Times, Verso, 1994.

Ashley Richard K. ve R. B. J. Walker, "Speaking the Language of Exile: Dissidence in International Studies," International Studies Quarterly, Cilt 34, No. 3, Eylül 1990, s. 259-268.

Baldwin, David (der.), Neorealism and Neoliberalism: The Contemporary Debate, New York, Columbia University Press, 1993.

Bedirhanoğlu, Pınar, “The State in Neoliberal Globalization: The Merits and Limits of Coxian Conceptions”, Allison Ayers (der.), Gramsci Political Economy and International Relations Theory, Palgrave Macmillan, 2008, s. 125-147.

Berki, R. N., "On Marxian Thought and the Problem of International Relations," World Politics, Ekim 1971, s. 80-105.

Brecher, Michael, "International Studies in the Twentieth Century and Beyond: Flawed Dichotomies, Synthesis, Cumulation”, International Studies Quarterly, No. 43, 1999, s. 213-264.

Benner, Erica L, "Marx and Engels on Nationalism and National Identity: A Reappraisal", Millennium, Cilt 17, No. 1, 1988, 1-23.

Brewer, Anthony, Marxist Theories of Imperialism, Londra, Routledge, 2002.

Bromley, Simon, Rethinking Middle East, University of Texas Press, 1994.

Burnham, Peter, "Neo-Gramscian Hegemony and the International Order", Andreas Bieler vd. (der.), Global Restructuring, State, Capital and Labour, Contesting Neo-Gramscian Perspectives, New York, Palgrave, 2006, 28-45.

Buzan, Barry ve Richard Little, "Why International Relations has Failed as an Intellectual Project and What to do About it?", Millenium, Cilt 30, No. 1, 2001, s. 19-39.

Callinicos, Alex, "Does Capitalism Need the States System?", Cambridge Review of International Affairs, Cilt 20, No. 4, Aralık 2007, s. 533-549.

Cardoso, Fernando Henrique and Enzo Faletto, Dependency and Development in Latin America, University of California Press, 1979.

Cox, Robert ve Michael Schechter, The Political Economy of a Plural World, Londra, Routledge, 2002.

Cox, Robert, “Global Perestroika”, Robert Cox ve Timothy Sinclair, Approaches to World Order, Cambridge, Cambridge University Press, 1996, s. 296-314.

Cox, Robert, “Gramsci, Hegemony, and International Relations: An Essay in Method”, Robert Cox ve Timoth Sinclair, Approaches to World Order, Cambridge, Cambridge University Press, 1996, s. 162-175.

Cox, Robert, "Postcript 1985", Robert Keohane (der.), Neorealism and its Critics, New York, Columbia University Press, 1986, s. 204-254.

Cox, Robert, "Social Forces, States and World Orders: Beyond International Relations Theory”, Millennium, Cilt 10, No. 2, 1981, s. 126-155.

Cox, Robert, “The Way Ahead: Toward a New Ontology of World Order”, Richard Wyn Jones (der.), Critical Theory and World Politics, Boulder, Lynne Rienner Pub., 2001, s. 45-59. 
Davenport, Andrew, “Marxism in IR: Condemned to a Realist Fate?", European Journal of International Relations, Cilt 19, No. 1, Mart 2013, s. 27-48.

der Derian, James ve Michael Shapiro (der.), International/Intertextual Relations: Postmodern Readings of World Politics, New York, Lexington Books, 1989.

Dos Santos, Theotonio, “The Structure of Dependence”, American Economic Review, No. 60, 1970, s. 231-236.

Dougherty ve Pfaltzgraff, Contending Theories of International Relations, Pearson, 2009.

Emmanuel, Arghiri, Unequal Exchange, Londra, New Left Books, 1972.

Eralp, Atila (der.), Devlet, Sistem, Kimlik, İstanbul, İletişim, 1996.

Evans, Peter, Dependent Development, Princeton, Princeton University Press, 1979.

Frank, Andre Gunder, Capitalism and Underdevelopment in Latin America: Historical Studies of Chile and Brazil, Londra, Monthly Review Press, 1969.

Forman, Michael, Nationalism and the International Labor Movement, University Park PA, Penn State University, 1998.

Gamble, Andrew, "Marxism After Communism: Beyond Realism and Historicism”, Review of International Studies, Cilt 25, No. 5, Aralık 1999, s. 127-144.

Gill, Stephen, "Epistemology, Ontology and the Italian School”, Stephen Gill (der.), Gramsci, Historical Materialism and International Relations, Cambridge, Cambridge University Press, 1993, s. 21-49.

Gill, Stephen, “Globalisation, Market Civilisation and Disciplinary Neoliberalism”, Millennium, Cilt 24, No. 3, 1995 , s. 399-423.

Gill, Stephen, "The Global Panopticon? The Neoliberal State, Economic Life and Democratic Surveillance", Alternatives, Cilt 20, No.1, 1995, s.1-49.

Gilman, Nils, Mandarins of the Future, Baltimore, The Johns Hopkins University Press, 2003.

Griffiths, Martin, Fifty Key Thinkers in International Relations, Londra, Routledge, 1999.

Gülalp, Haldun, Yeni Marksizm Teorilerinin Eleștirileri, İstanbul, Birikim Yayınları, 1979.

Halliday, Fred "Vigilantism in International Relations: Kubalkova, Cruickshank and Marxist Theory," Review of International Studies, Cilt 13, No. 3, 1987, s.163-176.

Halliday, Fred, Rethinking International Relations, Vancouver, UBC Press, 1995.

Hardt, Michael ve Anthony Negri, İmparatorluk, İstanbul, Ayrıntı, 2003.

Harvey, David, Yeni Emperyalizm, İstanbul, Everest Yayınları, 2004.

Held, David, An Introduction to Critical Theory, Londra, Polity Press, 1990.

Hilferding, Rudolf Finans Kapital, İstanbul, Belge Yay. 1995.

Hobson, John, "Back to the Future of 'One Logic or Two': Forward of the Past of 'Anarchy versus Hierarchy'?", Cambridge Review of International Affairs, Cilt 20, No. 4, Aralık 2007, s. 581-597.

Holsti, Kalevi, The Dividing Discipline, Hegemony and Diversity in International Theory, Londra, Allen \& Unwin, 1985.

Ikenberry, John, "Liberal Realism: The Foundations of a Democratic Foreign Policy", The National Interest, Sonbahar 2004, s. 38-51.

Immanuel Wallerstein, Geopolitics and Geoculture: Essays on the Changing World-System, Cambridge University Press, 1991.

Jessop, Bob, The Capitalist State, New York University Press, 1982.

Joseph, Jonathan, "On the Limits of Neo-Gramscian International Relations: A Scientific Realist Account of Hegemony," Allison Ayers (der.), Gramsci, Political Economy and International Relations Theory, Palgrave Macmillan, 2008, s. 101-125.

Kahler, Miles, "Inventing International Relations: IR Theory after 1945," Michael Doyle ve John Ikenberry (der.), New Thinking in IR Theory, Westview Press, 1997, s. 20-53; 
Katzenstein, Peter, Robert Keohane ve Stephen Krasner, "International Organization and the Study of World Politics," International Organization, Cilt 52, 1998, s. 645-685.

Kegley, Charles (der.), Controversies in International Relations: Realism and the Neoliberal Challenge, New York, St. Martin's Press, 1995.

Keohane, Robert ve Joseph Nye, Power and Interdependence, Boston, Little Brown, 1977.

Keohane, Robert, After Hegemony, New Jersey, Princeton University Press, 1984.

Keyman, Fuat, Küreselleşme, Devlet, Kimlik/Farklılık, İstanbul, Alfa, 2000.

Kubálková, V. ve A. Cruickshank, Marxism-Leninism and the Theory of International Relations, Londra, Routledge, 1980.

Kubálková, V. ve A. Cruickshank, Marxism and International Relations, Oxford, Oxford University Press, 1989.

Laclau, Ernest, "Feudalism and Capitalism in Latin America”, New Left Review, Sayı 67, Mayıs-Haziran 1971.

Lenin, V.I., Emperyalizm: Kapitalizmin En Üst Aşaması, Ankara, Sol Yayınları, 1965.

Linklater, Andrew, "Marxism," Scott Burchill vd., Theories of International Relations, 3. Baskı, Londra, Palgrave, 2006, s. 111-135.

Linklater, Andrew, "Realism, Marxism and Critical International Theory," Review of International Studies, Cilt 12, No. 4, Ekim 1986, s. 301-312.

Lukács, György, History and Class Consciousness: Studies in Marxist Dialectics, Cambridge, Mass., MIT Press, 1971.

Love, Joseph L., “The Origins of Dependency Analysis”, Journal of Latin American Studies, No. 22, 1990, s. 143-168.

Maclean, John, “Marxism and International Relations: A Strange Case of Mutual Neglect”, Millennium, Cilt 17, No. 2, Haziran 1988, s. 295-310.

Marx, Karl and Friedrich Engels, The Communist Manifesto, Echo Library, 2009.

Marx, Karl ve Friedrich Engels, The German Ideology, International Publishers Co, 1970.

Marx, Karl, “The British Rule in India,” The New York Daily Tribune, 25 Haziran 1853. <http://www.marxists. org/archive/marx/works/1853/06/25.htm>

Marx, Karl, 1844 El Yazmaları: Ekonomi Politik Ve Felsefe, (çev. Kenan Somer), Ankara: Sol Yayınları, 1993.

Marx, Karl, A Contribution to the Critique of Political Economy, BiblioBazaar, 2011.

Marx, Karl, Capital: A Critique of Political Economy, Cilt 1, New York, Penguin Books, 1976.

Morgenthau, Hans, Politics Among Nations: The Struggle for Power and Peace, New York, Knopf, 1967.

Niebhur, Reinhold, Moral Man and Immoral Society, Kentucky, John Knox Press, (1932)1960.

Nimni, Efraim, Marxism and Nationalism, Londra, Pluto Press, 1991.

Nye, Joseph, “Toward a Liberal Realist Foreign Policy”, Harvard Magazine, Mart-Nisan 2008, s. 36-40.

Özdemir, Ali Murat, Uluslarm Sefaleti, Ankara, İmge Kitabevi, 2010.

Pozo-Martin, Gonzalo, “Autonomous or Materialist Geopolitics?”, Cambridge Review of International Affairs, Cilt 20, No 4, Arallk 2007, s. 551-563.

Quijano, Anibal ve Immanuel Wallerstein, "Americanity As a Concept: Or the Americas in the Modern WorldSystem”, ISSA, Say1 1,1992, s. 549-557.

Rich, Paul, "Reinventing Peace: David Davies, Alfred Zimmern and Liberal Internationalism in Interwar Britain”, International Relations, Cilt 16, No. 2, Nisan 2002, s. 117-133.

Robinson, William, "Capitalist Globalization and Transnationalization of the State," Mark Rupert ve Hazel Smith (der.), Historical Materialism and Globalization, Routledge, 2002, s. 210-230.

Rosenberg, Justin, The Empire of Civil Society, Londra, Verso, 1994.

Rostow, Walt Whitman, The Stages of Economic Growth: A Non-Communist Manifesto, Cambridge, Cambridge University Press, 1990. 
Savran, Sungur, Kod Adı Küreselleşme: 21. Yüzyılda Emperyalizm, İstanbul, Yordam Kitap, 2008.

Singer, David, “The Level of Analysis in International Relations," World Politics, Cilt 14, No. 1, Ekim 1961, s. 77-92.

Smith, Hazel, "Silence of the Academics: International Social Theory, Historical Materialism and Political Values", Review of International Studies, Cilt 22, No. 2, Nisan 1996, s. 191-212.

Smith, Steve, "The United States and the Discipline of International Relations: Hegemonic Country Hegemonic Discipline”, International Studies Review, Cilt 4, No. 2, Yaz 2002, s. 67-85.

Teschke, Benno ve Hannes Lacher, “The Changing 'Logics' of Capitalist Competition,' Cambridge Review of International Affairs, Cilt 20, No 4, Aralık 2007, s. 565-580.

Thomas, Chantal, "Max Weber, Talcott Parsons and the Sociology of Legal Reform: A Reassessment with Implications for Law and Development," Minnesota Journal of International Law, No. 15, 2006, s. 383-424.

Uzgel, İlhan, Ulusal Çıkar ve Dış Politika, Ankara, İmge, 2004.

van der Pijl, Kees, The Making of an Atlantic Ruling Class, Londra, Verso, 1984.

van der Pjil, Kees, Global Rivalries, from the Cold War to Iraq, Londra, Pluto Press, 2006.

Viotti, Paul ve Mark Kauppi, International Relations Theory, New York, MacMillan, 1993.

Waever, Ole, “The Rise and Fall of the Inter-paradigm Debate," Steve Smith, et al. (der.), International Theory: Positivism and Beyond, Cambridge, Cambridge University Press, 1996, s. 149-186.

Waever, Ole, “The Sociology of a Not So International Discipline: American and European Developments in International Relations", International Organization, Cilt 52, 1998, s. 687-727.

Wallerstein, Immanuel, Geopolitics and Geoculture: Essays on the Changing World-System, Cambridge University Press, 1991.

Wallerstein, Immanuel, Amerikan Gücünün Gerileyişi, İstanbul, Metis, 2004.

Waltz, Kenneth, Man, the State and War, New York, Columbia University Press, 1954.

Waltz, Kenneth, The Theory of International Politics, Addison-Wesley Pub., 1979.

Wendt, Alexander, The Social Theory of International Politics, Cambridge, Cambridge University Press, 1999. 